\title{
IgG-Assisted Age-Dependent Clearance of Alzheimer's Amyloid $\beta$ Peptide by the Blood-Brain Barrier Neonatal Fc Receptor
}

\author{
Rashid Deane, ${ }^{1 *}$ Abhay Sagare, ${ }^{1 *}$ Katie Hamm, ${ }^{1}$ Margaret Parisi, ${ }^{1}$ Barbra LaRue, ${ }^{1}$ Huang Guo, ${ }^{1}$ Zhenhua Wu, ${ }^{1}$ \\ David M. Holtzman, ${ }^{2}$ and Berislav V. Zlokovic ${ }^{1}$ \\ ${ }^{1}$ Frank P. Smith Laboratories for Neuroscience and Neurosurgical Research, Department of Neurosurgery and Division of Neurovascular Biology, Arthur \\ Kornberg Medical Research Building, University of Rochester Medical Center, Rochester, New York 14642, and ${ }^{2}$ Departments of Neurology, and Molecular \\ Biology and Pharmacology, Washington University School of Medicine, St. Louis, Missouri 63110
}

The role of blood- brain barrier (BBB) transport in clearance of amyloid $\beta$-peptide $(\mathrm{A} \beta)$ by $\mathrm{A} \beta$ immunotherapy is not fully understood. To address this issue, we studied the effects of peripherally and centrally administered A $\beta$-specific IgG on BBB influx of circulating A $\beta$ and efflux of brain-derived $\mathrm{A} \beta$ in $A P P s w^{+/-}$mice, a model that develops Alzheimer's disease-like amyloid pathology, and wild-type mice. Our data show that anti-A $\beta$ IgG blocks the BBB influx of circulating $\mathrm{A} \beta$ in $A P P s w^{+/-}$mice and penetrates into the brain to sequester brain $\mathrm{A} \beta$. In young mice, $\mathrm{A} \beta$-anti-A $\beta$ complexes were cleared from brain to blood by transcytosis across the $\mathrm{BBB}$ via the neonatal $\mathrm{Fc}$ receptor $(\mathrm{FcRn})$ and the low-density lipoprotein receptor-related protein (LRP), whereas in older mice, there was an age-dependent increase in FcRn-mediated IgG-assisted A $\beta$ BBB efflux and a decrease in LRP-mediated clearance of A $\beta$-anti-A $\beta$ complexes. Inhibition of the FcRn pathway in older APPs $w^{+/-}$mice blocked clearance of endogenous $\mathrm{A} \beta 40 / 42$ by centrally administered $\mathrm{A} \beta$ immunotherapy. Moreover, deletion of the FcRn gene in wild-type mice inhibited clearance of endogenous mouse $A \beta 40 / 42$ by systemically administered anti-A $\beta$. Our data suggest that the FcRn pathway at the BBB plays a crucial role in IgG-assisted A $\beta$ removal from the aging brain.

Key words: antibody; amyloid $\beta$; Alzheimer's disease; blood-brain barrier; amyloid; transport

\section{Introduction}

Although the amyloid hypothesis of Alzheimer's disease (AD) remains controversial, many investigators consider accumulation of neurotoxic amyloid $\beta$ peptide $(\mathrm{A} \beta)$ in the brain as a key pathogenic event contributing to neurodegeneration (Hardy and Selkoe, 2002). The levels of $A \beta$ in the brain are controlled by its rates of production from the larger $\mathrm{A} \beta$-precursor protein (APP) and the rates of clearance (Tanzi et al., 2004; Zlokovic, 2005). According to recent studies, the blood-brain barrier (BBB) transport of $\mathrm{A} \beta$ critically regulates the levels of brain $\mathrm{A} \beta$ and particularly the receptor for advanced glycation end products (RAGE)-mediated influx of circulating A $\beta$ (Deane et al., 2003) and the low-density lipoprotein receptor-related protein 1 (LRP)-mediated efflux of brain-derived A $\beta$ (Shibata et al., 2000; Deane et al., 2004). Under physiological conditions, the LRPmediated brain efflux of $A \beta$ prevails, whereas in animal models of $\mathrm{AD}$ and in $\mathrm{AD}$ brains, downregulation of LRP in concert with

\footnotetext{
Received Sept. 1, 2005; revised 0ct. 29, 2005; accepted 0ct. 30, 2005.

This research was supported by United States Public Health Service Grants R37AG023084 and NS34467 (B.V.Z.) and AG20222 (D.M.H.). We thank Dr. Derry Roopenian from The Jackson Laboratory for providing $\mathrm{FcRn}{ }^{-1-}$ mice, Bristol Myers Squibb for providing us with some aged Tg2576 mice, and Kelly Simons for assistance with animal breeding and maintenance.

${ }^{*}$ R.D. and A.S. contributed equally to this work.

Correspondence should be addressed to Berislav V. Zlokovic, Arthur Kornberg Medical Research Building, 601 Elmwood Avenue, Box 670, Rochester, NY 14642. E-mail: berislav_zlokovic@urmc.rochester.edu. DOI:10.1523/JNEUROSCI.3697-05.2005

Copyright $\odot 2005$ Society for Neuroscience 0270-6474/05/2511495-09\$15.00/0
}

upregulation of RAGE may create an unfavorable $A \beta$ gradient across the $\mathrm{BBB}$, resulting in $\mathrm{A} \beta$ retention in the brain (Tanzi et al., 2004; Zlokovic, 2004).

Vaccination and passive immunization to $\mathrm{A} \beta$ lower brain $\mathrm{A} \beta$ (Schenk et al., 1999; Sigurdsson et al., 2001; Das et al., 2003) and improve behavior in animal models of AD (Janus et al., 2000; Morgan et al., 2000; Dodart et al., 2002). Although clinical A $\beta$ immunization trials in $\mathrm{AD}$ patients were terminated because of adverse neuroinflammatory effect (Orgogozo et al., 2003), reduced $\mathrm{A} \beta$ brain deposition (Nicoll et al., 2003) and slower cognitive decline (Hock et al., 2003) have been reported. How anti-A $\beta$ IgG clears brain $A \beta$ remains debatable. The "sink" theory suggests that the interaction of $A \beta$ with an $A \beta$-specific IgG in plasma creates a concentration gradient across the BBB that promotes efflux of brain $A \beta$ into blood, as shown by passive and active immunization studies (DeMattos et al., 2001, 2002; Deane et al., 2003; Lemere et al., 2003). Conversely, some circulating anti-A $\beta$ antibodies cross the $\mathrm{BBB}$ and activate microgliamediated Fc $\gamma$ receptor-dependent $(\mathrm{FcR} \gamma)$ clearance of amyloid (Bard et al., 2000) and/or the FcR $\gamma$-independent clearance (Bacskai et al., 2002; Das et al., 2003). Microglia clear amyloid slowly (Frautschy et al., 1992; Paresce et al., 1997; Bacskai et al., 2002), whereas microglia-independent clearance of $A \beta$ seems to be more rapid (DeMattos et al., 2001; Wilcock et al., 2003; Deane et al., 2004) and may require efflux of $A \beta$ across the BBB (Shibata et al., 2000; Banks et al., 2003; Tanzi et al., 2004; Zlokovic, 2004). 
Here, we show in APPsw ${ }^{+/-}$mice (Hsiao et al., 1996), a model that develops $\mathrm{AD}$-like amyloid pathology, that an $\mathrm{A} \beta$-specific IgG prevents RAGE-mediated transport of circulating $A \beta$ across the $\mathrm{BBB}$ and enters into the brain to sequester brain $\mathrm{A} \beta$ and promote its vigorous clearance to blood. We demonstrated that the major histocompatibility complex class I-related neonatal Fc receptor $(\mathrm{FcRn})$, which is functionally and structurally distinct from the Fc $\gamma$ receptors (Borvak et al., 1998; Ravetch and Bolland, 2001; Roopenian et al., 2003; Ober et al., 2004; Yoshida et al., 2004), is critical for the IgG clearance from brain and for the elimination of $A \beta$-anti- $A \beta$ complexes through the $\mathrm{BBB}$. We also show that FcRn-mediated IgG-assisted A $\beta$ efflux across the BBB remains active with aging, in contrast to LRP-mediated clearance of $\mathrm{A} \beta$-anti-A $\beta$ complexes, which decreases with aging. Finally, we demonstrate that inhibition of the FcRn pathway in old $A P P s w^{+/-}$mice (Hsiao et al., 1996) completely blocks rapid clearance of endogenous $A \beta 40 / 42$ by centrally administered $A \beta$ immunotherapy, whereas deletion of the FcRn gene in mice inhibits clearance of endogenous mouse brain $\mathrm{A} \beta$ by systemically administered anti-A $\beta$.

\section{Materials and Methods}

Animals. C57BL/6 and APPsw ${ }^{+/-}$(transgenic Tg2576) mice were from Taconic Farms (Germantown, NY). $\beta_{2} M^{-/-}$mice (neonatal Fc receptor light chain $\beta 2$-microglobulin null mice), $F c R \gamma^{-/-}$mice (Fc $\gamma$ receptor null mice), $R A P^{-1-}$ (receptor-associated protein null mice), and $F c R n^{-1-}$ mice (neonatal Fc receptor null mice) were from The Jackson Laboratory (Bar Harbor, ME). Mice were anesthetized by ketamine (100 $\mathrm{mg} / \mathrm{kg}$, i.p.) and xylazine $(10 \mathrm{mg} / \mathrm{kg}$, i.p.). All procedures were according to National Institutes of Health guidelines approved by the University Committee on Animal Resources (University of Rochester).

Reagents. Human A $\beta 1-40$ was synthesized at the W. M. Keck Facility (Yale University, New Haven, CT), using solid-phase $N-t$ butyloxycarbonyl chemistry and purified by HPLC. We used human recombinant RAP (EMD Biosciences, San Diego, CA), monoclonal mouse antibody $(\mathrm{ab})$ against $\mathrm{C}$-terminal domain of human LRP $\beta$-chain, which cross reacts with mouse LRP (5A6, 1:350, $5 \mu \mathrm{g} / \mathrm{ml}$; EMD Biosciences), rat anti-mouse CD31 antibody (1:200; BD PharMingen, Lexington, KY), anti-RAGE IgG F $\left(\mathrm{ab}^{\prime}\right)_{2}(20 \mu \mathrm{g} / \mathrm{ml}$; Dr. Shi Du Yan, Columbia University, New York, NY), rat anti-mouse F4/80, a microglial cell marker (1:100; Serotec, Indianapolis, IN), mouse anti-human GFAP (1: 100; DakoCytomation, Glostrup, Denmark), mouse monoclonal antiphosphotyrosine (1:2500; Sigma, St. Louis, MO), and monoclonal mouse anti-human A $\beta$ (4G8; Signet Laboratories, Dedham, MA) against amino acids $17-24$ of $A \beta$. Monoclonal anti-FcRn (1G3) was obtained as the condition medium of cultured mouse hybridoma cell line CRL-2434 (American Type Culture Collection, Manassas, VA) as described previously (Schlachetzki et al., 2002). The FcRn blocking antibody does not interact with 4G8 in vitro, as indicated by 4G8 ELISA (see below), which showed no change in 4G8 signal in the presence of the FcRn antibody. $4 \mathrm{G} 8 \mathrm{~F}\left(\mathrm{ab}^{\prime}\right)_{2}$ was prepared as described previously (Pierce, Rockford, IL) and dialyzed overnight to remove elution buffer and digestion medium. The monoclonal antibody 1560 , which recognizes $A \beta$ epitope $1-17$, was from Chemicon (Temecula, CA). All chemicals were obtained from Sigma, except protease inhibitor (Roche, Indianapolis, IN) and Triton $\mathrm{X}-100$ (Electron Microscopy Sciences, Gibbstown, NJ). ${ }^{125} \mathrm{I}-\mathrm{Na}$ and ${ }^{14} \mathrm{C}-$ inulin were from Amersham Biosciences (Little, Chalfont, UK). ${ }^{99 \mathrm{~m}} \mathrm{Tc}$ was obtained from Cardinal Health 414 (Rochester, NY).

Radio-iodinated ligands. Radio-iodination of the $\mathrm{A} \beta$ peptide $(10 \mu \mathrm{g})$ was performed by mild "lactoperoxidase" method (Thorell and Johansson, 1971) using $2 \mathrm{mCi}^{125} \mathrm{I}$-Na. The mono-iodinated nonoxidized form of $\mathrm{A} \beta$ was purified by reverse-phase HPLC separation (Shibata et al., 2000 ). Typically, the specific activities were in the range of $45-65 \mu \mathrm{Ci} / \mu \mathrm{g}$ peptide. 4G8 $(50 \mu \mathrm{g})$ and $4 \mathrm{G} 8 \mathrm{~F}\left(\mathrm{ab}^{\prime}\right)_{2}(10 \mu \mathrm{g})$ were radio-iodinated using IODO-BEADS or IODO-GEN (Pierce) and 0.5 and $0.7 \mathrm{mCi}{ }^{125} \mathrm{I}-$ $\mathrm{Na}$, respectively. Typical specific activity was $\sim 3-5 \mu \mathrm{Ci} / \mu \mathrm{g} 4 \mathrm{G} 8$ or $4 \mathrm{G} 8$ $\mathrm{F}\left(\mathrm{ab}^{\prime}\right)_{2}{ }^{125} \mathrm{I}-\mathrm{A} \beta 40-4 \mathrm{G} 8$ complex was prepared by incubating ${ }^{125} \mathrm{I}-$
A $\beta 40$ with $4 \mathrm{G} 8$ at $5: 1$ molar ratio for $3 \mathrm{~h}$ at $37^{\circ} \mathrm{C}$, and excess ${ }^{125} \mathrm{I}-\mathrm{A} \beta$ was removed by ultrafiltration. Complex stability was confirmed by Tristricine native PAGE and autoradiography. ${ }^{125} \mathrm{I}-\mathrm{A} \beta-4 \mathrm{G} 8$ complex was prepared in a similar manner.

Brain perfusion technique. This method is used to determine influx of radiolabeled ligands across the BBB and has been described in detail previously (LaRue et al., 2004). Briefly, the right common carotid artery was cannulated with a polyethylene tubing (PE10), and the brains were perfused at $1.0 \mathrm{ml} / \mathrm{min}$ (Ranin peristaltic pump), with an artificial plasma solution as described previously (LaRue et al., 2004). Radiolabeled test ligands (e.g., ${ }^{125} \mathrm{I}-\mathrm{A} \beta 40,{ }^{125} \mathrm{I}-4 \mathrm{G} 8-\mathrm{A} \beta 40$, and ${ }^{125} \mathrm{I}-\mathrm{A} \beta 40-$ $4 \mathrm{G} 8$ ) and the reference molecules (e.g., ${ }^{14} \mathrm{C}$-inulin and ${ }^{99} \mathrm{Tc}$-albumin) were infused simultaneously via a slow-drive syringe pump (Harvard Apparatus, Holliston, MA) at a rate of $0.1 \mathrm{ml} / \mathrm{min}$. Influx of ${ }^{125} \mathrm{I}-\mathrm{A} \beta 40$ in $A P P s w^{+/-}$mice was determined at carrier concentrations corresponding to A $\beta 40$ plasma levels in $A P P s w^{+/-}$mice at different ages (Kawarabayashi et al., 2001). The effect of RAGE-specific $\operatorname{IgG~F}\left(\mathrm{ab}^{\prime}\right)_{2}$ was tested at $20 \mu \mathrm{g} / \mathrm{ml}$. After a timed perfusion, typically 5-10 min, the brain was rapidly removed, and the ipsilateral hemisphere was homogenized for radioactivity quantification. The perfusion fluid was centrifuged, and supernatant (plasma) was counted. ${ }^{125}$ I samples were subjected to TCA, SDS-PAGE, native PAGE, and/or HPLC analysis using the procedures we described previously (Shibata et al., 2000; Deane et al., 2003, 2004).

Brain clearance studies. Clearance of ${ }^{125} \mathrm{I}-\mathrm{A} \beta 40,{ }^{125} \mathrm{I}-4 \mathrm{G} 8$, or ${ }^{125} \mathrm{I}-\mathrm{A} \beta$ $4 \mathrm{G} 8$ from brain interstitial fluid (ISF) was determined simultaneously with ${ }^{14} \mathrm{C}$-inulin (reference marker), using a procedure described previously (Shibata et al., 2000). Briefly, a stainless steel guide cannula was implanted stereotaxically into the right caudate-putamen with the cannula tip coordinates of $0.9 \mathrm{~mm}$ anterior and $1.9 \mathrm{~mm}$ lateral to bregma and $2.9 \mathrm{~mm}$ below the surface of the brain. Animals were recovered after surgery before tracer studies. The experiments were performed before substantial chronic processes occurred, as assessed by histological analysis of tissue, i.e., negative staining for astrocytes (glial fibrillar acidic protein) and activated microglia (anti-phosphotyrosine), but allowing time for the BBB repair for large molecules, as reported previously (Cirrito et al., 2003; Deane et al., 2004). Isotope mixture (0.5 $\mu \mathrm{l})$ containing ${ }^{125}$ I-labeled test molecule at $40 \mathrm{~nm}$ and ${ }^{14} \mathrm{C}$-inulin was injected over 5 min via an ultra micropump with a micro4-controller (World Precision Instruments, Sarasota, FL) into brain ISF. The recovery of both radiolabeled inulin and $\mathrm{A} \beta$ at zero time was $100 \%$, indicating that $100 \%$ of injected material remains present for transport with no loss of tracers via tracking up the cannula. $4 \mathrm{G} 8$ was administered by two intraperitoneal injections at $200 \mu \mathrm{g}$ at 0 and $48 \mathrm{~h}$, and ${ }^{125} \mathrm{I}-\mathrm{A} \beta 40$ clearance was measured at 1 and $120 \mathrm{~h}$ of $4 \mathrm{G} 8$ administration in nontransgenic mice and at $120 \mathrm{~h}$ in 18- to 20-month-old APPsw ${ }^{+/-}$mice. The levels of 4G8 in plasma and brain ISF within $120 \mathrm{~h}$ were determined by ELISA (see below). Unlabeled molecular reagents [4G8 $(0.5$ and $2 \mu \mathrm{M})$, anti-FcRn $(\alpha \mathrm{FcRn}, 60 \mu \mathrm{g} / \mathrm{ml})$, RAP $(0.5$ and $5 \mu \mathrm{M})$, and fucoidan $(1.5 \mathrm{~mm})]$ were infused into brain ISF in control mice $30 \mathrm{~min}$ before radiolabeled ligands and then simultaneously with radioligands until the end of experiment. Clearance of ${ }^{125} \mathrm{I}$ $4 \mathrm{G} 8$ or ${ }^{125} \mathrm{I}-\mathrm{A} \beta-4 \mathrm{G} 8$ was also studied in $\mathrm{FCRn}^{-/-}, \beta_{2} \mathrm{M}^{-/-}, R A P^{-/-}$, or $F c R \gamma^{-/-}$mice. In all studies, brains were sampled within 30 min after tracer injection and prepared for radioactivity analysis. TCA and/or SDSPAGE/immunoprecipitation analyses were determined to confirm the molecular forms of test tracers in brain and plasma (Deane et al., 2003, 2004).

Brain capillary uptake. Brain capillaries from wild-type and APPsw ${ }^{+/-}$ mice were isolated as described previously (Wu et al., 2003) and incubated with ${ }^{125} \mathrm{I}-4 \mathrm{G} 8,{ }^{125} \mathrm{I}-\mathrm{A} \beta 40-4 \mathrm{G} 8$, or ${ }^{125} \mathrm{I}-4 \mathrm{G} 8-\mathrm{A} \beta 40$ at $1 \mathrm{~nm}$ and ${ }^{14} \mathrm{C}$-inulin in mock CSF at $37^{\circ} \mathrm{C}$ for $1 \mathrm{~min}$. The following potential inhibitors were used: $4 \mathrm{G} 8(0.5$ and $2 \mu \mathrm{M}), \operatorname{RAP}(0.5$ and $5 \mu \mathrm{M}), \mathrm{Fc}$ fragment ( 1 and $10 \mu \mathrm{M})$, and LRP-specific IgG $(20 \mu \mathrm{g} / \mathrm{ml})$. The capillary pellet was separated by centrifugation at $4^{\circ} \mathrm{C}$, washed in ice-cold mock CSF, and prepared for radioactivity analysis along with samples of the incubating medium.

Radioactivity measurements. ${ }^{125} \mathrm{I}$ samples and ${ }^{99} \mathrm{Tc}$-albumin radioactivity analysis were determined by gamma counter analysis (Wallac Vizard Gamma Counter; PerkinElmer, Meriden, CT). ${ }^{14} \mathrm{C}$ samples were solubilized in $0.5 \mathrm{ml}$ of tissue solubilizer (PerkinElmer) overnight, fol- 
lowed by addition of $5 \mathrm{ml}$ of scintillation cocktail (Packard Ultima Gold; PerkinElmer) and analysis on a liquid scintillation counter (Packard TriCarb 2100TR Liquid Scintillation Counter; PerkinElmer).

Calculations. The BBB influx was determined as cerebrovascular permeability surface area product (PS) $\times \mathrm{Cpl}$, where $\mathrm{Cpl}$ was the concentration of the test molecule in plasma. The PS product of $\left[{ }^{125} \mathrm{I}\right]$-labeled test molecule was calculated using ${ }^{14} \mathrm{C}$-inulin correction: PS $\times T=$ $\left[\left({ }^{125} \mathrm{I} \mathrm{cpm} / \mathrm{g}\right.\right.$ of brain tissue $) \times$ TCA-precipitable radioactivity $/\left({ }^{125} \mathrm{I}\right.$ $\mathrm{cpm} / \mathrm{ml}$ of arterial plasma inflow) $\times$ TCA-precipitable radioactivity] $\left({ }^{14} \mathrm{C} \mathrm{dpm} / \mathrm{g}\right.$ of brain tissue $) /\left({ }^{14} \mathrm{C} \mathrm{dpm} / \mathrm{ml}\right.$ of arterial plasma inflow $\left.)\right]$ (LaRue et al., 2004), where $T$ is the infusion time and ${ }^{14} \mathrm{C}$-inulin was infused simultaneously with the test molecule. Influx was expressed per gram brain ISF, assuming the ISF space of $0.1 \mathrm{ml} / \mathrm{g}$ of brain (LaRue et al., 2004).

For brain clearance studies, calculations of clearance parameters were as reported previously (Shibata et al., 2000). The percentage of radioactivity of the test ligand and inulin was determined as follows: \% recovery in brain $=100 \times\left(N_{b} / N_{i}\right)$, where, $N_{b}$ is the radioactivity remaining in the brain at the end of the experiment, and $N_{i}$ is the radioactivity injected into the brain ISF, i.e., the disintegrations per minute for ${ }^{14} \mathrm{C}$-inulin and the counts per minute for TCA-precipitable ${ }^{125}$ I-radioactivity. The percentage of ${ }^{125} \mathrm{I}$-labeled test ligands (i.e., 4G8, A $\beta 40-4 \mathrm{G} 8$, and $\mathrm{A} \beta 40$ ) cleared through the BBB was calculated as $\left[\left(1-N_{b(\text { TEST })} / N_{i(\text { TEST })}\right)-\right.$ $\left.\left(1-N_{b(\text { inulin })} / N_{i(\text { inulin })}\right)\right] \times 100$, using a standard time of $30 \mathrm{~min}$. The loss of tracers via the ISF bulk flow was used to calculate the percentage clearance of ${ }^{125}$ I-labeled test ligands via the flow of brain ISF and was calculated as $\left(1-N_{b \text { (inulin) }} / N_{i \text { (inulin) }}\right) \times 100$ (Shibata et al., 2000).

Brain capillary uptake of ${ }^{125}$ I-labeled test molecules [4G8, 4G8-A $\beta$, and $\mathrm{A} \beta-4 \mathrm{G} 8-\mathrm{F}\left(\mathrm{ab}^{\prime}\right)_{2}$ ] were corrected for the distribution of ${ }^{14} \mathrm{C}$-inulin and determined as the tissue to medium ratio as follows: cpm for TCAprecipitable ${ }^{125} \mathrm{I}$-radioactivity (g capillary protein)/cpm for TCAprecipitable ${ }^{125}$ I-radioactivity ( $\mathrm{ml}$ medium), as reported previously (Deane et al., 2004).

4 G8 ELISA. 4G8 titers in plasma and brain were determined within $120 \mathrm{~h}$ after two intraperitoneal injections of $4 \mathrm{G} 8(200 \mu \mathrm{g} / \mathrm{each})$ at 0 and $48 \mathrm{~h}$ by ELISA technique similar to that described previously (Das et al., 2001). Briefly, A $\beta 42$ was coated at $5 \mu \mathrm{g} /$ well overnight at $4^{\circ} \mathrm{C}$ in $50 \mathrm{~mm}$ carbonate buffer, $\mathrm{pH}$ 9.6, and $0.05 \%$ sodium azide on 96-well highbinding Stripwell immunoassay plates (Corning Life Sciences, Corning, $\mathrm{NY}$ ) and blocked with $0.25 \%$ bovine serum albumin in PBS overnight at $4^{\circ} \mathrm{C}$. After three washes with PBS/0.1\% Tween $20,100 \mu$ l of diluted plasma or brain homogenates were added and incubated overnight at $4^{\circ} \mathrm{C}$. After washes with $\mathrm{PBS} / 0.1 \%$ Tween 20 , plasma and brain $4 \mathrm{G} 8$ was detected using a goat anti-mouse conjugated with HRP (Sigma) and tetramethylbenzidine (TMB) substrate (Kirkegaard \& Perry Laboratories, Gaithersburg, MD). 4G8 levels were obtained from the standard curve. The levels of $4 \mathrm{G} 8$ in plasma and brain ISF were expressed in nanomolar assuming the ISF volume of distribution of $0.1 \mathrm{ml} / \mathrm{g}$ brain.

Immunohistological analysis. Freshly frozen acetone-fixed brain tissues from $A P P s w^{+/-}$and control mice cut in the sagittal plane at $14 \mu \mathrm{m}$, and paraffin-embedded human brain tissue from $\mathrm{AD}$ patients [Braak stage V-VI, CERAD (for Consortium to Establish a Registry for Alzheimer's Disease), frequent] and age-matched controls (Braak negative; CERAD negative) cut in $6 \mu \mathrm{m}$ sections were used for double immunostaining for FcRn and CD31 or von Willebrand Factor (vWF) (endothelial cell marker). Anti-FcRn antibodies were prepared from the condition medium from $1 \mathrm{G} 3$ cells. Biotinylated anti-mouse IgG was used as a secondary antibody and was detected with fluorescein streptavidin (1:1000; Vector Laboratories, Burlingame, CA). M.O.M kit (Vector Laboratories) was used to block endogenous IgG in studies on mouse brain tissue. For CD31 staining, mouse CD31-specific IgG was used as a primary antibody, and Alexa Fluor 594 donkey anti-rat IgG (1:500; Invitrogen, Carlsbad, CA) was used as a secondary antibody. The anti-vWF primary antibody was detected with fluorescein goat anti-rabbit IgG (1:150; Invitrogen). Image analysis was performed using Olympus Optical (Tokyo, Japan) AX70 microscope equipped with the SPOT digital camera. Ten randomly selected fields in each region from 10 sections spanning the entire hemisphere from four mice per group or from Brodman areas
9/10 in humans were analyzed as we reported previously (Deane et al., 2004).

Western blotting. The cerebrovascular mouse system was washed with $100 \mathrm{ml}$ of ice-cold PBS by cardiac perfusion, and cerebral microvessels were isolated as described previously (Zlokovic et al., 1993). Protein homogenates $(5-15 \mu \mathrm{g})$ were separated under reducing conditions (FcRn) or nonreducing conditions (GFAP and F4/80), electroblotted in Tris-glycine buffer on nitrocellulose membrane, and probed with antiFcRn (1:1), anti-GFAP (1:100), or F4/80 (1:100). The signal was detected by enhanced chemiluminescence detection system (Amersham Biosciences, Piscataway, NJ).

${ }^{125} \mathrm{I}-A \beta 40-4 G 8$ complex in brain. After $120 \mathrm{~h}$ of the intraperitoneal $4 \mathrm{G} 8(200 \mu \mathrm{g})$ administration at 0 and $48 \mathrm{~h}, 120 \mathrm{~nm}{ }^{125} \mathrm{I}-\mathrm{A} \beta 40$ was microinfused into brain ISF in the caudate nucleus. After $30 \mathrm{~min}$, the brain was removed, homogenized in cold PBS containing complete proteinase inhibitor cocktail (Roche), and centrifuged at $18,000 \times g$ for $30 \mathrm{~min}$ at $4^{\circ} \mathrm{C}$. The supernatant was concentrated by lyophilization and analyzed by 4-20\% Tris-tricine native gel electrophoresis, followed by autoradiography.

$A \beta$ immunotherapy and $A \beta$ quantification. Twenty 4-month-old $A P P s w^{+/-}$mice were anesthetized as above (see above, Animals) and placed in a stereotactic apparatus. $4 \mathrm{G} 8$ was injected into the right hippocampus (ipsilateral) in mock CSF in a volume of $0.5 \mu$ lover 5 min through a 33 gauge injector attached to a $10 \mu \mathrm{l}$ Hamilton syringe. As a negative control for $4 \mathrm{G} 8$, a rabbit anti-mouse IgG against divalent metal transporter-1, which does not interact with $\mathrm{A} \beta$ but has an intact $\mathrm{Fc}$ region to interact with the $\mathrm{FcRn}$ receptor at the $\mathrm{BBB}$, was injected into the contralateral hippocampus in the same animal [nonimmune IgG (NI $\mathrm{IgG})]$. The coordinates with respect to bregma were $-2.7 \mathrm{~mm}$ posterior, $+2.5 \mathrm{~mm}$ lateral, and $-3.0 \mathrm{~mm}$ ventral to the skull. The following test antibodies were injected: $4 \mathrm{G} 8(2 \mu \mathrm{g} / 0.5 \mu \mathrm{l}) ; \alpha \mathrm{FcRn}$ (anti-FcRn antibody, $10 \mu \mathrm{g} / 0.5 \mu \mathrm{l})$ followed by $4 \mathrm{G} 8(2 \mu \mathrm{g} / 0.5 \mu \mathrm{l}) 30 \mathrm{~min}$ after $\alpha \mathrm{FcRn}$; NI-IgG $(2 \mu \mathrm{g} / 0.5 \mu \mathrm{l})$ followed by $4 \mathrm{G} 8(2 \mu \mathrm{g} / 0.5 \mu \mathrm{l}) 30 \mathrm{~min}$ after NI-IgG; and 4G8 $\mathrm{F}\left(\mathrm{ab}^{\prime}\right)_{2}(2 \mu \mathrm{g} / 0.5 \mu \mathrm{l})$. Brains were analyzed after $24 \mathrm{~h}$.

Brain sections were incubated with rabbit polyclonal anti-pan-A $\beta$ (1: 100; BioSource International, Camarillo, CA) overnight at $4^{\circ} \mathrm{C}$, washed, and incubated in Alexa Fluor 488-conjugated goat anti-rabbit IgG (1: 200; Invitrogen) for $1 \mathrm{~h}$ at a room temperature. Photomicrographs of hippocampi were taken using an AX70 Olympus Optical microscope (Spectra Services, Ontario, NY). The percentage difference between ipsilateral and contralateral hippocampus was determined as [ (number of pixels ipsilateral - number of pixels contralateral)/number of pixels contralateral] $\times 100$ (Oddo et al., 2004).

$\mathrm{A} \beta 40$ and $\mathrm{A} \beta 42$ were quantified by a sandwich ELISA kit (Signet Laboratories) according to the instructions of the manufacturer. $A \beta$ levels were expressed as the percentage change between the ipsilateral compared with the contralateral hippocampus using the following formula: $[\mathrm{A} \beta$ (ng/section) in the ipsilateral hemisphere $-\mathrm{A} \beta(\mathrm{ng} / \mathrm{section})$ in the contralateral hemisphere $] /[\mathrm{A} \beta$ (ng/section) in the contralateral hemisphere] $\times 100$.

For soluble brain $A \beta$ oligomer analysis, $A \beta$ was extracted from 10 brain sections from the site of 4G8 or vehicle injection in $200 \mu \mathrm{l}$ of TBS buffer containing complete protease inhibitor cocktail (Roche), and separated from the insoluble pellet by centrifugation at $20,000 \times g$ for 30 min. Antibody 6E10 (Signet Laboratories) was used as the capturing and detection antibody to determine relative levels of TBS-extracted soluble $\mathrm{A} \beta$ oligomers, by using a sandwich ELISA similar to those described previously with different capturing/detecting antibodies (LeVine, 2004; Yang et al., 2005). In this assay, soluble $\mathrm{A} \beta$ oligomers captured by $6 \mathrm{E} 10$ can only be detected by biotinylated 6E10 (detecting antibody), if there is at least one more accessible epitope for the detecting biotinylated $6 \mathrm{E} 10$ antibody on $\mathrm{A} \beta$ oligomers. For the detection of biotinylated $6 \mathrm{E} 10$ antibody, streptavidin-HRP (BioSource International) was incubated for $2 \mathrm{~h}$ at room temperature and visualized using TMB substrate (Kirkegaard \& Perry Laboratories). This method did not detect monomeric $\mathrm{A} \beta$ but detected soluble $\mathrm{A} \beta 40$ or $\mathrm{A} \beta 42$ oligomers of different sizes prepared in vitro, as described previously (Kayed et al., 2003) (data not shown). 4G8, at the levels used in intracerebral clearance studies, did not interfere with the 6 E10 sandwich ELISA (data not shown). The optical density readings reflecting the number of accessible epitopes on $\mathrm{A} \beta$ oligomers were nor- 
malized per total TBS-soluble brain protein to estimate the relative levels of oligomers.

The thioflavin S-positive amyloid load (Wilcock et al., 2003) was determined using the Image-Pro-Plus program (Media Cybernetics, Silver Spring, MD).

Mouse endogenous brain $A \beta$. Mouse endogenous $A \beta 40$ and $A \beta 42$ levels were determined by sandwich ELISA (Best et al., 2005). Cerebral cortex was homogenized in $2 \%$ SDS containing complete protease inhibitor cocktail (Roche) (Kawarabayashi et al., 2001). For mouse A $\beta 40$ specific sandwich ELISA, the capturing and biotinylated detecting antibodies were mouse monoclonal mouse $\mathrm{A} \beta$ raised against amino acid residues 1-20 (AMB0062; BioSource International) and rabbit polyclonal anti-A $\beta 40$ biotin conjugate (44-3489; BioSource International), respectively. For mouse A $\beta 42$-specific sandwich ELISA, the capturing and detecting antibody were AMB0062 and rabbit polyclonal anti-A $\beta 42$ biotin conjugate (44-3449; BioSource International), respectively. $\mathrm{Mu}-$ rine synthetic $\mathrm{A} \beta 40$ and $\mathrm{A} \beta 42$ standards (American Peptide, Sunnyvale, CA) were prepared in the ELISA buffer (PBS, $0.05 \%$ Tween $20,0.25 \%$ BSA, $0.05 \%$ sodium azide, and complete protease inhibitor cocktail). The capturing antibody was coated at $5 \mu \mathrm{g} / \mathrm{ml}$ overnight at $4^{\circ} \mathrm{C}$ in $50 \mathrm{~mm}$ carbonate buffer, pH 9.6, and $0.05 \%$ sodium azide on 96-well highbinding Stripwell immunoassay plates (Corning Life Sciences), blocked with $0.25 \%$ bovine serum albumin in PBS overnight at $4^{\circ} \mathrm{C}$, and $100 \mu \mathrm{l}$ of sample or standard was added and incubated overnight at $4^{\circ} \mathrm{C}$. A $\beta$ levels were obtained from the standard curve.

Statistical analysis. The results were compared by multifactorial analysis of variance and Student's $t$ test. The differences were considered to be significant at $p<0.05$. All values are mean \pm SEM.

\section{Results}

Figure $1 A$ shows that $4 \mathrm{G} 8$, an $\mathrm{A} \beta$-specific monoclonal IgG2b raised to $17-24$ residues of $A \beta$, reduces by fivefold to sixfold influx of circulating ${ }^{125} \mathrm{I}-\mathrm{A} \beta 40$ across the $\mathrm{BBB}$ in $A P P s w^{+/-}$ (Tg2576) mice at 2-3 and 4-6 months of age. At a later stage, 15to 20 -month-old $A P P s w^{+/-}$mice, the influx of circulating $\mathrm{A} \beta$ into brain ISF, although significantly higher than in controls, declines spontaneously. Still, 4G8 produced a significant inhibition of $\mathrm{A} \beta$ influx in 15- to 20-month-old and 24- to 36-monthold $A P P s w^{+/-}$mice (Fig. $1 A$ ).

In the cerebral arterial inflow, ${ }^{125} \mathrm{I}-\mathrm{A} \beta 40$ alone remains $>98.5 \%$ in its free monomeric form, as shown by the SDS-PAGE and HPLC analysis (Fig. $1 B$ ), as reported previously (Deane et al., 2003). However, in the presence of $4 \mathrm{G} 8, \mathrm{~A} \beta$ forms stable complexes in plasma, as demonstrated by the SDS-PAGE and HPLC analysis within $30 \mathrm{~min}$ of the cerebral arterial infusion (Fig. 1C), which is longer than typical infusion times of 5-10 min used for influx calculations in Figure $1 \mathrm{~A}$. In the present study, the concentrations of $4 \mathrm{G} 8$ that block $\mathrm{A} \beta 40 \mathrm{BBB}$ influx (Fig. $1 A$ ) were by two orders of magnitude lower than previously reported anti-A $\beta$ IgG plasma levels in actively (Das et al., 2003) or passively (DeMattos et al., 2002) immunized mice. Lowering the $4 \mathrm{G} 8 / \mathrm{A} \beta 40$ plasma ratio from 80 to 1 resulted in comparable $>95 \%$ inhibition of $\mathrm{A} \beta 40$ brain uptake (Fig. $1 D$ ). A $\beta 40-4 \mathrm{G} 8$ complexes labeled on either $\mathrm{A} \beta$ or $4 \mathrm{G} 8$ residues did not penetrate across the $\mathrm{BBB}$, and their behavior was not influenced by an RAGE blocking antibody. In contrast, a significant transport of free, circulating $A \beta$ was by $>80 \%$ inhibited by the blockade of RAGE at the BBB (Fig. $1 E$ ), as reported previously (Deane et al., 2003; LaRue et al., 2004). These findings suggest that $4 \mathrm{G} 8$ effectively reduces RAGE-mediated increase in circulating $\mathrm{A} \beta$ influx across the $\mathrm{BBB}$ in $A P P s w^{+/-}$mice by sequestering circulating $A \beta$ in plasma.

Figure 2, $A$ and $B$, shows time-dependent $4 \mathrm{G} 8$ increases in plasma and brain ISF, respectively, within $120 \mathrm{~h}$ of two subsequent intraperitoneal injections of $4 \mathrm{G} 8(200 \mu \mathrm{g})$. By using a brain clearance method (Shibata et al., 2000), we showed that efflux of
A

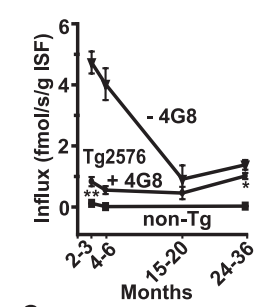

B

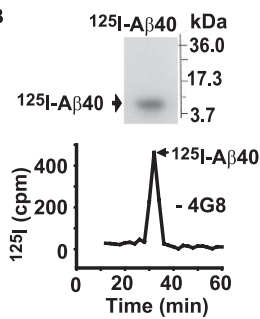

C
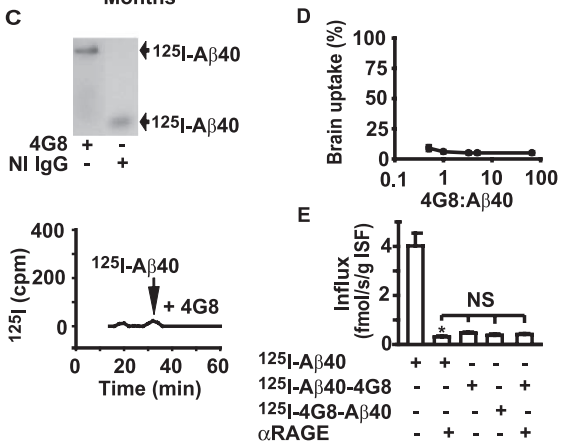

Figure 1. $A \beta$-specific lgG (4G8) blocks $B B B$ influx of circulating $A \beta 40 . A, A \beta 40 B B B$ influx in $\mathrm{APPSW}^{+/-}$(Tg2576) mice in the presence (circles) and absence (triangles) of a fourfold excess of $4 \mathrm{G} 8$ determined with the brain perfusion method (LaRue et al., 2004) with ${ }^{125} \mathrm{I}-\mathrm{A} \beta 40$ at carrier concentrations corresponding to A $\beta 40$ plasma levels in Tg2576 mice at different ages (Kawarabayashi et al., 2001), i.e., $4 \mathrm{~nm}$ ( $2-3$ and $4-6$ months), $3 \mathrm{~nm}$ (15-20 months), and 1.5 nм (24-36 months), and in age-matched littermate controls (non-Tg) at physiological A $\beta 40$ plasma levels (50 pM) without 4G8. B, Tris-tricine SDS-PAGE (top) and HPLC (bottom) analysis of ${ }^{125}$ I-A $\beta 40$ radioactivity in the arterial inflow without $4 G 8$. C, Tris-tricine native PAGE (top) and HPLC (bottom) analysis of ${ }^{125} \mathrm{I}-\mathrm{A} \beta 40$ radioactivity in the arterial inflow with a fourfold excess of $4 G 8$ or NI lgG. $D$, ${ }^{125}$ I-A $\beta 40$ brain uptake at varying $4 G 8 / A \beta 40$ plasma ratio in 4- to 6-monthold Tg2576 mice expressed as the percentage of control uptake. $\boldsymbol{E}$, Transport across the BBB of ${ }^{125}$ I-A $\beta 40$ and $A \beta 40-4 G 8$ complexes labeled on either $A \beta 40$ or $4 G 8$ in the absence and presence of RAGE-specific lgG F(ab' $)_{2}$ in 4- to 6-month-old Tg2576 mice. Mean \pm SEM; $n=$ $3-6 .{ }^{*} p<0.001$; and ${ }^{* *} p<0.05$; NS, not significant.

centrally administered ${ }^{125} \mathrm{I}-\mathrm{A} \beta 40$ from mouse brain ISF determined over 30 min was moderately but significantly increased by $15 \%$ at $1 \mathrm{~h}$ of peripheral $4 \mathrm{G} 8$ intraperitoneal administration (Fig. $2 C)$. Because the levels of $4 \mathrm{G} 8$ in brain ISF were barely detectable after 1 h of peripheral $4 \mathrm{G} 8$ injections (Fig. $2 \mathrm{~B}$ ) and intracerebrally administered ${ }^{125} \mathrm{I}-\mathrm{A} \beta 40$ does not form complexes with plasmaderived $4 \mathrm{G} 8$ after $1 \mathrm{~h}$ of peripheral $4 \mathrm{G} 8$ administration, as indicated by the autoradiographic analysis of brain aqueous extracts (Fig. 2E), an increase in brain to blood clearance of centrally administered $\mathrm{A} \beta$ at this early time point is likely to be mediated by peripheral action of $4 \mathrm{G} 8$. Thus, an increased ${ }^{125} \mathrm{I}-\mathrm{A} \beta 40$ efflux at $1 \mathrm{~h}$ (Fig. $2 C$ ) probably reflects the sink effect of $4 \mathrm{G} 8$, similar to that reported for other peripheral $\mathrm{A} \beta$ sequestering agents by different groups (DeMattos et al., 2002; Deane et al., 2003; Lemere et al., 2003). Namely, after $1 \mathrm{~h}$, plasma levels of $4 \mathrm{G} 8$ are already high and $\sim 5 \mathrm{~nm}$ (Fig. $2 A$ ), which likely mops up completely the endogenous free plasma $A \beta(50-100 \mathrm{pM})$, alters the $A \beta$ equilibrium at the BBB in favor of $A \beta$ efflux from brain. However, after $120 \mathrm{~h}$ of two subsequent $4 \mathrm{G} 8$ systemic injections, the BBB efflux of ${ }^{125} \mathrm{I}-\mathrm{A} \beta 40$ was substantially increased by $50 \%$ (Fig. $2 \mathrm{D}$ ). Because at $120 \mathrm{~h}$ there was a significant increase in $4 \mathrm{G} 8$ levels in brain ISF (Fig. $2 B$ ), we hypothesized that enhanced clearance of centrally administered ${ }^{125} \mathrm{I}-\mathrm{A} \beta 40$ by peripherally administered $4 \mathrm{G} 8$ at $120 \mathrm{~h}$ (Fig. 2D) is not attributable to peripheral sink action (Fig. $2 \mathrm{~A}$ ). Indeed, the autoradiographic analysis of brain extracts indicated that intracerebrally administered ${ }^{125} \mathrm{I}-\mathrm{A} \beta 40$ forms within 30 min complexes with systemically administered $4 \mathrm{G} 8$ at $120 \mathrm{~h}$ of 4G8 administration (Fig. 2E). This result suggests that peripheral 

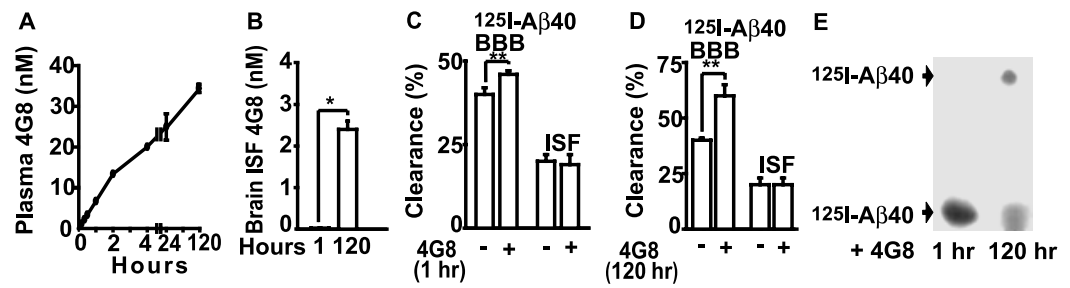

Figure 2. Plasma and brain ISF distribution of systemically administered $4 \mathrm{G} 8$ and its effect on ${ }^{125} \mathrm{I}-\mathrm{A} \beta 40$ clearance from brain ISF. A, Plasma 4G8 levels determined with ELISA within $120 \mathrm{~h}$ in mice that received $4 \mathrm{G} 8(200 \mu \mathrm{g})$ intraperitoneally at 0 and $48 \mathrm{~h}$. $B$, Brain ISF 4 G8 levels in mice in $A$ at 1 and $120 \mathrm{~h}$ of 4 G8 treatment. C, D, Clearance of ${ }^{125} \mathrm{I}-\mathrm{A} \beta 40$ (40 nM) via BBB transport and ISF bulk flow within 30 min of ${ }^{125} \mathrm{I}-\mathrm{A} \beta 40 /{ }^{14} \mathrm{C}$-inulin microinjections into brain ISF in mice at $1 \mathrm{~h}(\boldsymbol{C})$ and $120 \mathrm{~h}(\boldsymbol{D})$ of $4 \mathrm{G} 8$ treatment as in $\boldsymbol{A}$. $\boldsymbol{E}$, Formation of ${ }^{125} \mathrm{I}-\mathrm{A} \beta 40-4 \mathrm{G} 8$ complexes in mouse brain ISF determined by Tris-tricine native PAGE of the aqueous brain extracts $30 \mathrm{~min}$ after ${ }^{125} \mathrm{I}-\mathrm{A} \beta 40$ (120 nM) microinfusion into brain ISF and after either $1 \mathrm{~h}$ (left) or $120 \mathrm{~h}$ (right) of 4G8 treatment as in $\boldsymbol{A}$. Mean $\pm \mathrm{SEM} ; n=3-5 .{ }^{*} p<0.001$ and ${ }^{* *} p<0.05$.

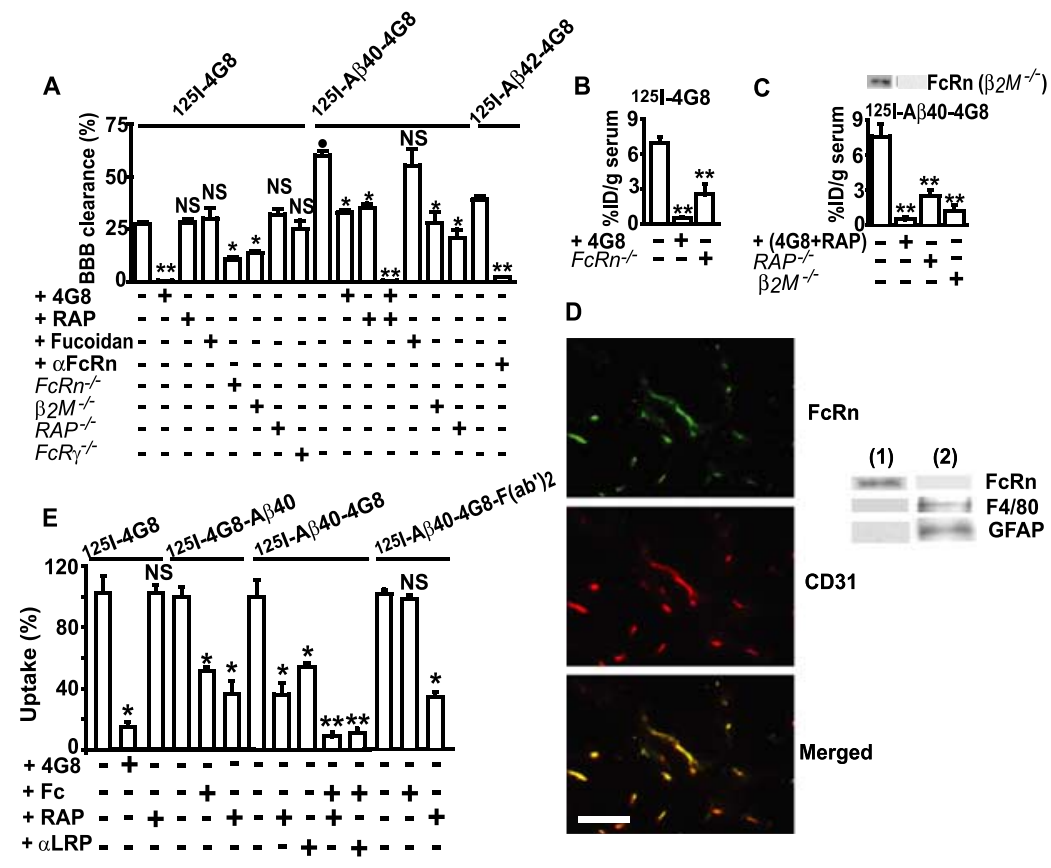

Figure 3. FcRn-mediated BBB transcytosis of ${ }^{125} \mid-4 \mathrm{G} 8,{ }^{125} \mathrm{I}-\mathrm{A} \beta 40-4 \mathrm{G} 8$, and ${ }^{125} \mathrm{I}-\mathrm{A} \beta 42-4 \mathrm{G} 8$ from brain to blood. $A$, The BBB clearance of $40 \mathrm{~nm}{ }^{125} \mathrm{I}-4 \mathrm{G} 8,{ }^{125} \mathrm{I}-\mathrm{A} \beta 40-4 \mathrm{G} 8$, or ${ }^{125} \mathrm{I}-\mathrm{A} \beta 42-4 \mathrm{G} 8$ within 30 min of brain ISF microinjections with and without unlabeled $4 \mathrm{~GB}(2 \mu \mathrm{M}), \operatorname{RAP}(5 \mu \mathrm{M})$, fucoidan $(1.5 \mathrm{mM}), \alpha \mathrm{FCRn}$ (anti-FcRn, $60 \mu \mathrm{g} / \mathrm{ml})$, and $\mathrm{A} \beta 40(1 \mu \mathrm{M})$ and in $F c R n^{-1-}$, $\beta_{2} M^{-/-}, R A P^{-/-}$, and $F C R \gamma^{-/-}$mice. $\boldsymbol{B}, \boldsymbol{C}$, Serum levels of ${ }^{125} \mathrm{I}-4 \mathrm{G} 8(\boldsymbol{B})$ and of ${ }^{125} \mathrm{I}-\mathrm{A} \beta 40-4 \mathrm{G} 8$ (C) from experiments in $\boldsymbol{A}$ expressed as the percentage of injected dose (\%ID). Western blot analysis of $\mathrm{FcRn}$ in brain microvessels in control and $\beta_{2} M^{-1-}$ mice (inset, C). D, FCRn/CD31 double immunostaining in brains of nontransgenic mice (left) Scale bar, $50 \mu \mathrm{m}$. Western blot analysis (right) of $F(R n, F 4 / 80$ (phagocytic cells), and GFAP (astrocytes) in isolated brain microvessels (lane 1 ) and capillarydepleted brain (lane 2). $\boldsymbol{E}$, Uptake of ${ }^{125} \mathrm{I}-4 \mathrm{G} 8,{ }^{125} \mathrm{I}-4 \mathrm{G} 8-\mathrm{A} \beta 40,{ }^{125} \mathrm{I}-\mathrm{A} \beta 40-4 \mathrm{G}$, or ${ }^{125} \mathrm{I}-\mathrm{A} \beta 40-4 \mathrm{G} 8-\mathrm{F}\left(\mathrm{ab}^{\prime}\right)_{2}(1 \mathrm{~nm})$ at the abluminal side of isolated mouse brain microvessels within $1 \mathrm{~min}$ at $37^{\circ} \mathrm{C}$. 4G8 $(5 \mu \mathrm{M}), \operatorname{RAP}(5 \mu \mathrm{M}), \operatorname{Fc}(10 \mu \mathrm{M})$, and $\alpha \operatorname{LRP}(20$ $\mu \mathrm{g} / \mathrm{ml})$ were applied as potential inhibitors. Mean \pm SEM; $n=3-5 .{ }^{*} p<0.05,{ }^{* *} p<0.001$, inhibitors or gene deletion versus the corresponding controls; $\bullet_{p}<0.01,{ }^{125} \mathrm{I}-\mathrm{A} \beta 40-4 \mathrm{G} 8$ versus ${ }^{125} \mathrm{I}-4 \mathrm{G} 8$; NS, not significant.

4G8 may enhance clearance of brain-borne $\mathrm{A} \beta$ after its crossing into brain ISF. ${ }^{125} \mathrm{I}-\mathrm{A} \beta 40$ clearance via the ISF bulk flow was not altered by $4 \mathrm{G} 8$.

To test whether $A \beta$ complexed to an $A \beta$-specific IgG is cleared from brain, we measured the BBB efflux of centrally administered $4 \mathrm{G} 8$ alone and of $\mathrm{A} \beta 40-4 \mathrm{G} 8$ and $\mathrm{A} \beta 42-4 \mathrm{G} 8$ complexes in wildtype 2- to 3-month-old mice, using our clearance method (Shibata et al., 2000). The BBB clearance of ${ }^{125} \mathrm{I}-4 \mathrm{G} 8$ was inhibited by the increasing concentrations of centrally administered unlabeled 4G8 (data not shown) and abolished by $2 \mu \mathrm{M} 4 \mathrm{G} 8$ (Fig. 3A), suggesting a concentration-dependent IgG transcytosis at the BBB. RAP, which inhibits A $\beta$ BBB clearance via LRP (Shibata et al., 2000; Deane et al., 2004), or fucoidan, an inhibitor of the scavenger receptor on microglia, did not affect $4 \mathrm{G} 8$ clearance (Fig. 3A). Immunostaining for activated microglia was negative in the present model (data not shown), as reported previously (Cirrito et al., 2003; Deane et al., 2004).

Because IgG is carried across biological membranes by the FcRn (Roopenian et al., 2003; Ober et al., 2004; Yoshida et al., 2004) and FcRn is expressed in vascular endothelium and at the BBB (Borvak et al., 1998; Schlachetzki et al., 2002), we explored whether deletions of the FcRn gene and the FcRn light chain $\beta_{2} M$ gene affect ${ }^{125}$ I-4G8 BBB efflux. Figure $3 A$ shows significantly reduced $4 \mathrm{G} 8$ clearance in $\mathrm{FcRn} n^{-1-}$ mice and $\beta_{2} M^{-/-}$mice by 68 and $63 \%$, respectively, whereas deletions of the $R A P$ gene (functional LRP knock-out) (Deane et al., 2004) or the $F c R \gamma$ gene were without effect. Excess of 4G8 in brain ISF in $\mathrm{FcRn} n^{-/-}$mice resulted in complete inhibition of ${ }^{125} \mathrm{I}-4 \mathrm{G} 8 \mathrm{BBB}$ efflux (data not shown), consistent with the data demonstrating that unlabeled $4 \mathrm{G} 8$ inhibits ${ }^{125} \mathrm{I}$ 4G8 clearance at the BBB in wild-type mice (Fig. 3A). After central administration of ${ }^{125} \mathrm{I}-4 \mathrm{G} 8$, the radioactivity appearing in plasma was readily detectable and 100\% TCA precipitable, suggesting transcytosis of intact ${ }^{125} \mathrm{I}-4 \mathrm{G} 8$ from brain into blood (Fig. $3 B$ ), as confirmed by the autoradiography (data not shown). ${ }^{125} \mathrm{I}-4 \mathrm{G} 8$ serum levels were significantly reduced $(>90 \%)$ by central administration of unlabeled excess $4 \mathrm{G} 8$ and in $\mathrm{FcRn} n^{-/-}$mice (70\%) (Fig. $3 B$ ), indicating that the FcRn pathway is required for clearance of an anti-A $\beta$ IgG across the BBB.

Next, we showed that ${ }^{125} \mathrm{I}-\mathrm{A} \beta 40-4 \mathrm{G} 8$ was cleared across the $\mathrm{BBB}$ of 2- to 3-month-old wild-type mice at a rate 2.5fold faster than ${ }^{125} \mathrm{I}-4 \mathrm{G} 8$ (Fig. $3 A$ ). Unlike $4 \mathrm{G} 8$, clearance of $\mathrm{A} \beta 40-4 \mathrm{G} 8$ complexes was inhibited by central administration of either unlabeled 4G8 or RAP and was abolished by the combination of both, suggesting that in young mice ${ }^{125} \mathrm{I}-\mathrm{A} \beta 40-4 \mathrm{G} 8$ complexes can be cleared by an IgGdependent mechanism and/or via a RAP-sensitive LRP mechanism (Shibata et al., 2000; Deane et al., 2004). That both the IgG-assisted and LRP-dependent transport are important for clearance of $\mathrm{A} \beta 40-4 \mathrm{G} 8$ complexes in young mice has been confirmed by demonstrating $\sim 60 \%$ reductions in ${ }^{125} \mathrm{I}-\mathrm{A} \beta 40-4 \mathrm{G} 8$ $\mathrm{BBB}$ efflux in $\beta_{2} M^{-/-}$mice and $R A P^{-/-}$mice (Fig. $3 A$ ). After central administration of ${ }^{125} \mathrm{I}-\mathrm{A} \beta-4 \mathrm{G} 8$ complexes, the radioactivity appearing in plasma was $100 \%$ TCA precipitable (Fig. $3 C$ ), suggesting no degradation of ${ }^{125} \mathrm{I}-\mathrm{A} \beta 40$ from the complex, as well as transcytosis of intact complexes, which has been confirmed by the autoradiography (data not shown). Serum levels of centrally infused ${ }^{125} \mathrm{I}-\mathrm{A} \beta 40-4 \mathrm{G} 8$ complexes were substantially 


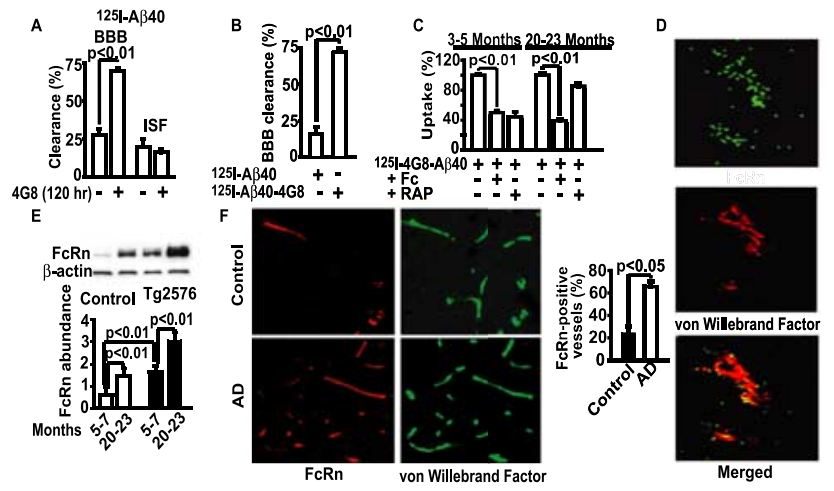

Figure 4. FcRn-dependent ${ }^{125} \mathrm{I}-\mathrm{A} \beta 40-4 \mathrm{G} 8 \mathrm{BBB}$ clearance in old $A P P s W^{+/-}$mice and $\mathrm{FcRn}$ BBB expression in AD. $A,{ }^{125} \mathrm{I}-\mathrm{A} \beta 40$ (40 nM) BBB and ISF clearance in 18- to 20-month-old APPsW $^{+/-}$(Tg2576) mice 30 min after brain ISF microinjections and $120 \mathrm{~h}$ after vehicle or $4 \mathrm{G} 8$ intraperitoneal treatment, as in Figure $2 A$. B , The BBB clearance of ${ }^{125} \mathrm{I}-\mathrm{A} \beta 40$ or ${ }^{125} \mathrm{I}-\mathrm{A} \beta 40$ $4 \mathrm{G} 8$ complexes ( $40 \mathrm{~nm}$ ) in 20- to 23-month-old $\mathrm{Tg} 2576$ mice within 30 min of brain ISF microinjections. C, ${ }^{125}$ I-A $\beta 40-4 G 8$ (1 nM) uptake by isolated cerebral microvessels of $\operatorname{Tg} 2576$ mice at 3-5 and $20-23$ months of age determined within $1 \mathrm{~min}$ at $37^{\circ} \mathrm{C}$ without and with $\mathrm{Fc}$ fragment $(10 \mu \mathrm{m})$ and RAP $(5 \mu \mathrm{m})$. D, FCRn colocalization with vWF (endothelial intracellular marker) in the brain of 10-month-old Tg2576 mouse studied by confocal microscopy. $\boldsymbol{E}$, Western blot analysis of FCRn in brain microvessels of control and Tg2576 mice at 5-7 and 20-23 months of age (top) and its relative abundance by scanning densitometry corrected for $\beta$-actin (bottom). $\boldsymbol{F}, \mathrm{FcRn}$ and vWF double immunostaining in brains of $A D$ and age-matched individuals (left) and FcRn-positive vascular profiles (right). Scale bar, $50 \mu \mathrm{m}$. Mean $\pm \mathrm{SEM} ; n=3-6$.

reduced by centrally administered unlabeled $4 \mathrm{G} 8$ and/or RAP, as well as by deletion of the $\beta_{2} M$ gene and RAP gene (Fig. $3 C$ ). We also demonstrated that $\mathrm{A} \beta 42-4 \mathrm{G} 8$ complexes are cleared by the FcRn pathway (Fig. $3 A$ ), as well as $\mathrm{A} \beta 42$ bound to anti-A $\beta 1560$ (data not shown).

By using isolated cerebral microvessels positive for FcRn and negative for microglia and astrocytic markers (Fig. 3D), we corroborated our in vivo findings by showing that ${ }^{125} \mathrm{I}-4 \mathrm{G} 8$ rapid brain capillary uptake at $37^{\circ} \mathrm{C}$, which reflects its clearance by brain capillaries, in 2- to 3-month-old mice was dose dependently (data not shown) and completely blocked by excess unlabeled 4G8 (Fig. 3E) but was not affected by RAP. Under the present experimental conditions, uptake of ${ }^{125} \mathrm{I}$-radiolabeled $4 \mathrm{G} 8$ and its complexes with $\mathrm{A} \beta$ occurred at the abluminal side of brain capillaries because short, 1 min exposure times precluded a significant diffusion of the studied tracers into the capillary lumen, which is required for the uptake at the luminal side (Deane et al., 2004). This has been confirmed by a negligible uptake of ${ }^{14} \mathrm{C}$-inulin, which does not interact with the cells and is taken up by the isolated capillaries only via passive diffusion into the lumen. Regarding ${ }^{125}$ I-labeled $4 \mathrm{G} 8-\mathrm{A} \beta 40$ complexes (with the label on either $4 \mathrm{G} 8$ or $\mathrm{A} \beta 40$ residues), both the unlabeled $\mathrm{Fc}$ fragment and RAP or an LRP-specific IgG blocked clearance of complexes on brain capillaries from 2- to 3-month-old young mice (Fig. $3 E$ ). As expected, $\mathrm{A} \beta 40-4 \mathrm{G} 8 \mathrm{~F}\left(\mathrm{ab}^{\prime}\right)_{2}$ complexes lacking the Fc domain were cleared by an Fc-independent RAPsensitive mechanism, confirming the involvement of LRP, as shown for $\mathrm{A} \beta$-mediated clearance (Deane et al., 2004). That $\mathrm{A} \beta$ molecule in anti-A $\beta-\mathrm{A} \beta$ complexes is critical for interaction with LRP was shown by inhibition of brain capillary clearance of ${ }^{125} \mathrm{I}$ labeled $4 \mathrm{G} 8-\mathrm{A} \beta 40$ complexes (the label was on $4 \mathrm{G} 8$ ) by excess of unlabeled $\mathrm{A} \beta 40$ (data not shown).

Figure $4 A$ shows that 4 G8 systemic administration over $120 \mathrm{~h}$ increases by approximately threefold efflux of centrally administered ${ }^{125} \mathrm{I}-\mathrm{A} \beta 40$ in 18 - to 20 -month-old $A P P s w^{+/-}$mice (Fig. $4 A)$. To test whether old $A P P s w^{+/-}$mice clear $\mathrm{A} \beta$ from brain through an IgG-assisted efflux, we compared clearance of A $\beta 40$ alone and $\mathrm{A} \beta 40-4 \mathrm{G} 8$ complexes. Consistent with a significant downregulation of LRP at the BBB with aging, and particularly in transgenic APPsw ${ }^{+/-}$mice (Deane et al., 2004), the BBB efflux of $\mathrm{A} \beta 40$ alone was significantly reduced in old $A P P s w^{+/-}$mice (Fig. $4 B$ ) compared with control young mice (Fig. $2 C, D$ ) or young $A P P s w^{+/-}$mice (data not shown). However, central infusion of ${ }^{125} \mathrm{I}-\mathrm{A} \beta 40-4 \mathrm{G} 8$ complexes in 20 - to 23 -month-old $A P P s w^{+/-}$ mice resulted in an approximately fivefold greater clearance than of ${ }^{125} \mathrm{I}$-A $\beta 40$ alone (Fig. $4 \mathrm{~B}$ ), suggesting that IgG-assisted efflux of $\mathrm{A} \beta$ remains active in old $A P P s w^{+/-}$mice and is even somewhat higher than in young control wild-type mice (Fig. $3 A$ ).

In a next set of studies, we showed that both RAP and Fc fragment effectively block clearance of $4 \mathrm{G} 8-\mathrm{A} \beta$ complexes on isolated cerebral microvessels derived from younger, 3- to 5-month-old $A P P s w^{+/-}$mice (Fig. 4C). In contrast, RAP did not block clearance of $4 \mathrm{G} 8-\mathrm{A} \beta$ complexes on brain capillaries derived from 20 - to 23 -month-old $A P P s w^{+/-}$mice (Fig. $4 C$ ). The loss of inhibitory effect of RAP on capillary clearance in aged $A P P s w^{+/-}$mice is consistent with a significant loss of LRP expression in these animals at an older age (Deane et al., 2004). Conversely, the $\mathrm{Fc}$ fragment inhibited significantly by $67 \%$ clearance of complexes on aged $A P P s w^{+/-}$mouse brain capillaries (Fig. $4 C$ ), confirming that an IgG-dependent clearance of IgG-A $\beta$ complexes remains functional with aging in $A P P s w^{+/-}$mice. These results are consistent with a significant FcRn expression in brain endothelium in older $A P P s w^{+/-}$mice and an agedependent increase in the FcRn levels in brain capillaries of $A P P s w^{+/-}$mice (Fig. 4D,E). We also observed an age-dependent increase in the FcRn levels in control mice, although the levels of FcRn in $A P P s w^{+/-}$mice were substantially higher than in their corresponding age-matched littermate controls, at both 5-7 and 20-23 months of age, respectively (Fig. 4E). Studies on human tissue indicated an increase in FcRn-positive brain vascular profiles in $\mathrm{AD}$ compared with age-matched controls (Fig. $4 F$ ).

Next, we determined whether inhibition of the FcRn pathway affects intracerebral 4G8 immunotherapy in 24-month-old $A P P s w^{+/-}$mice. We limited studies to $24 \mathrm{~h}$ to minimize possible influence of the antibody on microglia-dependent clearance, because microglia are typically activated in older $A P P s w^{+/-}$mice after $24 \mathrm{~h}$ of an anti-A $\beta$ antibody intracerebral injection (Wilcock et al., 2003), as confirmed in this study (data not shown). Our data corroborate findings by the previous studies (Wilcock et al., 2003; Oddo et al., 2004) by showing that centrally administered 2 $\mu \mathrm{g}$ of $4 \mathrm{G} 8$ significantly reduces $\mathrm{A} \beta$ immunostaining and the levels of human endogenous $A \beta 40$ and $A \beta 42$ in the hippocampus of 24 -month-old $A P P s w^{+/-}$mice by 45,47 , and $25 \%$, respectively (Fig. 5A,D-F). These results correlated well with the observed $>35 \%$ reductions in the levels of TBS-insoluble/SDS-soluble human endogenous $A \beta 40$ and $A \beta 42$ by $4 \mathrm{G} 8$. It is noteworthy that the levels of TBS-soluble human $\mathrm{A} \beta$ oligomers were also reduced by $25 \%$ by $4 \mathrm{G} 8$, as demonstrated by an ELISA developed previously for determining the relative levels of $\mathrm{A} \beta$ oligomers (Levine, 2004; Yang et al., 2005) (Fig. 5G). However, 4G8 did not affect thioflavin S-positive amyloid load (Fig. $5 \mathrm{H}$ ), consistent with our finding that $4 \mathrm{G} 8$ did not affect the levels of SDS-resistant/formic acid-soluble $A \beta 40$ and $A \beta 42$, using methods described previously (Kawarabayashi et al., 2001). This result corroborates findings by a previous study demonstrating that, within $24 \mathrm{~h}$ of intracerebral delivery, the $\mathrm{A} \beta$-specific antibody does not reduce thioflavin S staining (Wilcock et al., 2003). Although 4G8 binds amyloid plaques on tissue sections ex vivo, its binding to plaques 

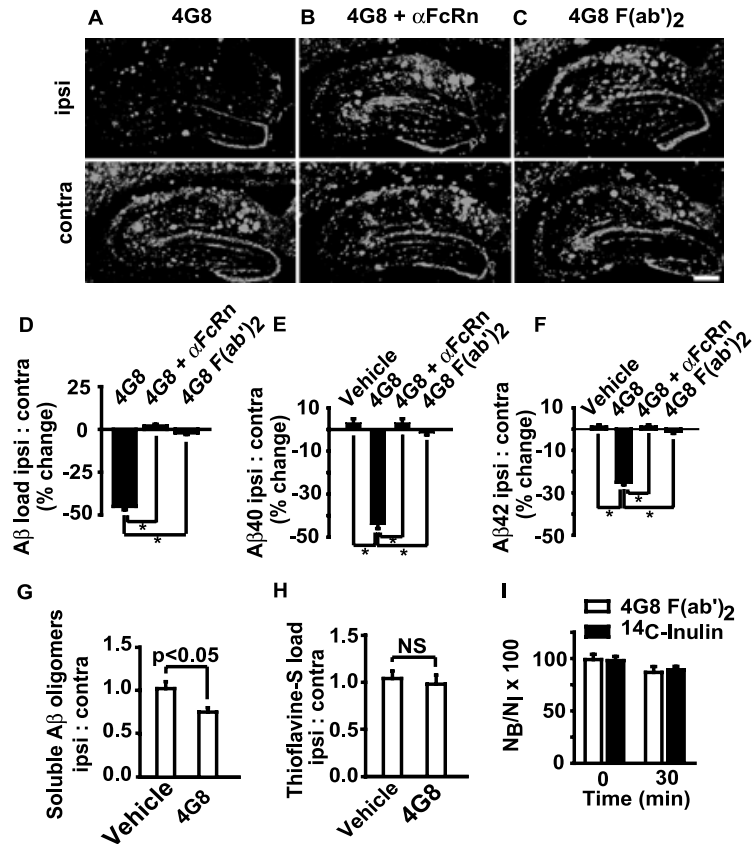

H
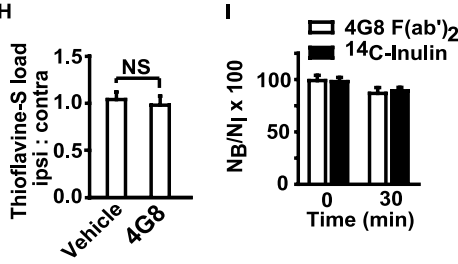

Figure 5. FcRn-dependent clearance of endogenous $A \beta$ in $A P P s W^{+/-}$mice by centrally administered 4G8. $A$, Intrahippocampal 4G8 $(2 \mu \mathrm{g} / 0.5 \mu \mathrm{l})$ reduces $A \beta$ immunostaining $24 \mathrm{~h}$ after injection in 24-month-old Tg2576 mouse (top; ipsi) compared with nonimmune lgGtreated contralateral hippocampus (bottom; contra). $\boldsymbol{B}, 4 \mathrm{G} 8(2 \mu \mathrm{g} / 0.5 \mu \mathrm{l}$ ) was injected into the ipsilateral hippocampus in 24-month-old Tg2576 mouse 30 min after $\alpha \mathrm{FcRn}$ (anti-FcRn antibody; $10 \mu \mathrm{g} / 0.5 \mu \mathrm{l}$ ) (top) or vehicle (bottom; contralateral hippocampus). C, 4G8 F(ab') 2 $\mu \mathrm{g} / 0.5 \mu \mathrm{l}$ ) injected into the hippocampus in 24-month-old Tg2576 mouse (top) versus vehicle-treated contralateral hippocampus (bottom). Scale bar, $350 \mu \mathrm{m}$. D-F, A $\beta$ load (D), $A \beta 40(\boldsymbol{E})$, and $A \beta 42(\boldsymbol{F})$ levels: the percentage change (\%) in the ipsilateral versus contralateral hippocampus in $\operatorname{Tg} 2576$ mice. ${ }^{*} p<0.05 . \mathbf{G}, \boldsymbol{H}$, TBS-soluble $A \beta$ oligomers (G) and thioflavin S-positive amyloid load $(\boldsymbol{H})$ in 4G8-treated (ipsilateral) versus vehicle-treated (contralateral) hippocampus in 24-month-old Tg2576 mice at $24 \mathrm{~h}$. Mean \pm SEM; $n=5$ mice per group and $6-8$ sections close to the injection site per mouse. $I,{ }^{125} \mathrm{I}-4 \mathrm{G} 8 \mathrm{~F}\left(\mathrm{abb}^{\prime}\right)_{2}(40 \mathrm{~nm})$ and ${ }^{14} \mathrm{C}$-inulin brain retention 30 min after brain ISF microinjection of the tracer mixture. Mean $\pm \mathrm{SEM} ; n=3$. NS, Not significant.

after intracerebral in vivo administration was minimal under the present experimental conditions (data not shown).

In contrast to vehicle-treated $A P P s w^{+/-}$mice, pretreatment of $A P P s w^{+/-}$mice with intracerebral infusions of FcRn-specific blocking antibodies 30 min before administration of 4G8 completely abolished $\mathrm{A} \beta$ lowering effects of centrally administered $4 \mathrm{G} 8$ immunotherapy (Fig. 5B,D-G). A nonimmune IgG did not have any effect on $\mathrm{A} \beta$ clearance (Fig. $5 A-C$, bottom). Similarly, within $24 \mathrm{~h}$, we failed to demonstrate significant reductions in $\mathrm{A} \beta$ load and $\mathrm{A} \beta 40$ and $\mathrm{A} \beta 42$ levels by $4 \mathrm{G} 8 \mathrm{~F}\left(\mathrm{ab}^{\prime}\right)_{2}$ in 24 -month-old $A P P s w^{+/-}$mice (Fig. $5 C-F$ ). Our clearance study with radiolabeled ${ }^{125} \mathrm{I}-4 \mathrm{G} 8 \mathrm{~F}\left(\mathrm{ab}^{\prime}\right)_{2}$ failed to show clearance of Fab fragments across the BBB (Fig. 5I), in contrast to a rapid removal of the full length $4 \mathrm{G} 8$ (Fig. 3A).

To determine whether the FcRn pathway is critical for removal of endogenous brain $\mathrm{A} \beta$ by systemically administered $4 \mathrm{G} 8$, we compared the effects of peripheral 4G8 immunotherapy (administered as in Fig. 2) on levels of endogenous mouse brain $\mathrm{A} \beta 40$ and $\mathrm{A} \beta 42$ in $\mathrm{FcRn} n^{+/+}$mice and $\mathrm{FCRn}^{-/-}$mice. To minimize a possible confounding effect of LRP-mediated clearance, we performed these studies in 9-month-old mice, at an age when LRP expression at the BBB is already substantially reduced in mice (Shibata et al., 2000; Deane et al., 2004), as confirmed in this study (data not shown). By using an ELISA similar to that reported recently (Best et al., 2005), we showed that treatment of
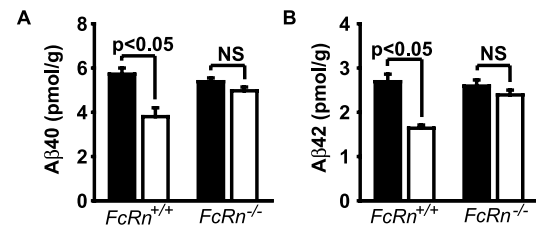

Figure 6. FcRn-dependent clearance of mouse endogenous brain $A \beta$ by $4 G 8$ systemic administration: studies in $\mathrm{FCRn}{ }^{+/+}$and $\mathrm{FCRn}{ }^{-/-}$mice. Mice were treated for $5 \mathrm{~d}$ with $4 \mathrm{G} 8$ (open bar), $200 \mu$ g intraperitoneally at 0 and $48 \mathrm{~h}$, or vehicle (filled bar), and the levels of endogenous mouse $A \beta 40(\boldsymbol{A})$ and $A \beta 42(\boldsymbol{B})$ determined in the cerebral cortex in $\mathrm{FcRn}{ }^{+/+}$mice and $F C R n^{-/-}$mice. Mean \pm SEM; $n=5$. NS, Not significant.

$\mathrm{FcRn} n^{+/+}$wild-type mice with systemically administered $4 \mathrm{G} 8$ results in significant 35 and $40 \%$ reductions in brain endogenous mouse $A \beta 40$ and $A \beta 42$ levels, respectively (Fig. $6 A, B$ ). In contrast, there was a negligible $5-7 \%$ reduction in endogenous $A \beta 40$ and $\mathrm{A} \beta 42$ brain levels in $\mathrm{FcRn} n^{-/-}$mice (Fig. $6 A, B$ ). A reduction in endogenous mouse brain $\mathrm{A} \beta$ levels by systemic $4 \mathrm{G} 8$ in $\mathrm{FcRn} n^{+/+}$mice compared with $\mathrm{FcRn}{ }^{-/-}$mice was associated with a corresponding significant increase in plasma $A \beta$, which was $>97 \%$ G-protein precipitable (G-protein binds the Fc fragment of $4 \mathrm{G} 8$ ) (data not shown), indicating that the majority of $A \beta$ in plasma after systemic therapy with the antibody is bound to $4 \mathrm{G} 8$, similarly as shown by previously passive and active immunization studies (DeMattos et al., 2001, 2002; Lemere et al., 2003).

\section{Discussion}

Our study shows that an anti-A $\beta$ antibody regulates brain $\mathrm{A} \beta$ by exerting important peripheral and central actions on $A \beta$ transport across the $\mathrm{BBB}$. The mechanism of peripheral $\mathrm{A} \beta$ sequestration observed in the present study with 4G8 in $A P P s w^{+/-}$mice may be similar to that of other $\mathrm{A} \beta$ binding agents, i.e., apolipoproteins E2 and 3 (Martel et al., 1997), ganglioside $M$ and gelsolin (Matsuoka et al., 2003), the soluble forms of RAGE (Deane et al., 2003) or LRP (Deane et al., 2004), and/or other antibodies to $\mathrm{A} \beta$ that reduce its influx across the $\mathrm{BBB}$ (Pan et al., 2002; Banks et al., 2005). This peripheral binding of $A \beta$ may create a sink effect, providing that the activity of the LRP efflux pathway (Deane et al., 2004) is not lost or is sufficient to maintain elimination of brain $\mathrm{A} \beta$ and $\mathrm{A} \beta-\mathrm{IgG}$ complexes. The central action of certain anti-A $\beta$ IgGs may, however, critically depend on sequestering brain $\mathrm{A} \beta$, followed by the $\mathrm{FcRn}$-mediated rapid $\mathrm{BBB}$ clearance. Importantly, the FcRn IgG-dependent clearance for $\mathrm{A} \beta$ remains active at the $\mathrm{BBB}$ during normal aging and in $A P P s w^{+/-}$mice, and increased FcRn expression at the BBB in AD may likely be of a therapeutic value for $A \beta$ immunotherapy.

Circulating IgG may enter the brain and have widespread extracellular distribution within the CNS and CSF from sites deficient in a BBB such as subarachoind space pial surface in the Wirchow-Robin spaces and subpial cortical gray matter and circumventricular organs (Balin et al., 1986; Kozlowski et al., 1990; Broadwell and Sofroniew, 1993). It has been reported that an antibody directed at $1-17$ region of $\mathrm{A} \beta$ can use the extracellular pathways for its passive entry into the CNS (Banks et al., 2002). In addition, some IgG species are also transported slowly across the BBB via adsorptive-mediated transcytosis (Zlokovic et al., 1990; Pardridge, 1991). Our results indicate that systemically administered 4G8 exerts a significant clearance effect on endogenous brain $\mathrm{A} \beta$ that is abolished in $F c R n^{-/-}$mice at an age when LRP expression is substantially downregulated (Deane et al., 2004). Although 4G8 recognizes APP in addition to $\mathrm{A} \beta$, it is unlikely that the $A \beta$-lowering effect of systemically administered $4 \mathrm{G} 8$ is attrib- 
utable to inhibition of $\mathrm{APP} / \mathrm{A} \beta$ production because this effect is lost in $\mathrm{FcRn} n^{-/-}$compared with $\mathrm{FcRn}{ }^{+/+}$mice. Inhibition of the FcRn pathway influences also the outcome of centrally administered $\mathrm{A} \beta$ immunotherapy in old $A P P s w^{+/-}$mice. Although intracerebral immunotherapy has limitations regarding direct insight into what happens with peripheral passive or active approaches, studies using the intracerebral approach have been useful in delineating clearance pathways of $A \beta$ from brain (Tanzi et al., 2004; Zlokovic, 2005) and have been used extensively to demonstrate that antibody in the brain exerts a clearance action on brain A $\beta$ (Bacskai et al., 2001, 2002; Wilcock et al., 2003; Oddo et al., 2004). For example, it has been shown that intracerebral delivery of $2 \mu \mathrm{g}$ of $4 \mathrm{G} 8$ or anti-A $\beta 1560$ (Oddo et al., 2004) and 2 $\mu \mathrm{g}$ of $6 \mathrm{E} 10$ (Wilcock et al., 2003), substantially reduces $\mathrm{A} \beta$ load in 12-month-old triple-transgenic AD mice and in 20-month-old $A P P s w^{+/-}$mice, respectively. Our data suggest that the FcRn pathway is required for clearance of TBS-insoluble/SDS-soluble endogenous $A \beta 40$ and $A \beta 42$, which possibly represents $A \beta$ in diffuse plaques that is not yet converted into a hard-core thioflavin S-positive amyloid. Although we have not demonstrated FcRn-mediated clearance of thioflavin-S-positive amyloid, it is possible that, over longer periods of time ( $>24 \mathrm{~h})$, centrally administered 4G8 will reduce thioflavin S-positive load from brain (Wilcock et al., 2003; Oddo et al., 2004), which, at least in part, could involve the FcRn pathway.

Topical administration of Fab fragments alone can reduce $\mathrm{A} \beta$ immunostaining in $A P P s w^{+/-}$mice within $3 \mathrm{~d}$ (Bacskai et al., 2002). Our data show that this effect could be mediated via LRP efflux system, which can clear $\mathrm{A} \beta 40-4 \mathrm{G} 8 \mathrm{~F}\left(\mathrm{ab}^{\prime}\right)_{2}$ complexes. In contrast, Fab fragments alone are eliminated slowly from brain ISF at a rate comparable with that of a reference marker, inulin. However, we also demonstrated that $4 \mathrm{G} 8 \mathrm{~F}\left(\mathrm{ab}^{\prime}\right)_{2}$ cannot exert a vigorous effect on $\mathrm{A} \beta$ pathology within $24 \mathrm{~h}$ in 24-month-old $A P P s w^{+/-}$mice, which could be explained by substantial downregulation of LRP levels at the $\mathrm{BBB}$ in old $A P P s w^{+/-}$mice (Deane et al., 2004).

FcRn plays a central role in delivering IgGs within and across the cells (Ober et al., 2004). Although FcRn was discovered as a developmental IgG receptor, recent studies suggest its expression in different cell types in adult rodents and humans, including polarized epithelia and endothelia, which are able to translocate the FcRn-bound cargo bidirectionally, from either the lumen or tissue spaces into the opposite pole of the cell (Roopenian et al., 2003; Yoshida et al., 2004). FcRn is directly involved in IgG exocytosis (Ober et al., 2004) and binds IgG best at an intracellular pH 6.0-6.5 (Roopenian et al., 2003). It is expressed at low levels in the cell membrane because of its rapid recycling after incomplete fusion with the plasma membrane, known as "kiss and run" (Ober et al., 2004). It is likely that the FcRn-mediated transcytosis of IgG across the BBB may require an additional binding step to another IgG receptor at the abluminal cell membrane, which will facilitate IgG endocytosis before its FcRn-mediated migration to the exocytotic site at the luminal membrane, analogous to the IgG transport across other biological membranes (Roopenian et al., 2003). This hypothesis is supported by our work in progress showing a single $55 \mathrm{kDa}$ band (data not shown) after biotinylation of the abluminal mouse brain capillary membranes and 4G8 affinity purification. This band corresponded to a recently described IgG cell surface receptor in the placental endothelium (Gafencu et al., 2003). The exact cellular mechanisms involved in possible interaction between a putative $55 \mathrm{kDa}$ IgG receptor and FcRn during IgG and $A \beta$-anti-A $\beta$ complex internalization at the abluminal side of the BBB and exocytosis across the luminal side remain, however, to be investigated.

Based on the present work, we propose two possibilities for enhanced efficacy of immunization therapy directed at an improved clearance of $\mathrm{A} \beta$ across the BBB: (1) to increase a peripheral sink of an anti-A $\beta$ antibody and facilitate brain efflux of $A \beta$ and $A \beta-I g G$ complexes by increasing the activity of the BBB LRP efflux pathway at an older age; and (2) to optimize the FcRn pathway for enhanced IgG-mediated $A \beta$ clearance across the $\mathrm{BBB}$ in the aging brain.

\section{References}

Bacskai BJ, Kajdasz ST, Christie RH, Carter C, Games D, Seubert P, Schenk D, Hyman BT (2001) Imaging of amyloid-beta deposits in brains of living mice permits direct observation of clearance of plaques with immunotherapy. Nat Med 7:369-372.

Bacskai BJ, Kajdasz ST, McLellan ME, Games D, Seubert P, Schenk D, Hyman BT (2002) Non-Fc-mediated mechanisms are involved in the clearance of amyloid- $\beta$ in vivo by immunotherapy. J Neurosci 22:7873-7878.

Balin BJ, Broadwell RD, Salcman M, El-Kalliny M (1986) Avenues for entry of peripherally administered protein to the central nervous system in mouse, rat and squirrel monkey. J Comp Neurol 251:260-280.

Banks WA, Terrell B, Farr SA, Robinson SM, Nonaka N, Morley JE (2002) Passage of amyloid $\beta$ protein antibody across the blood-brain barrier in a mouse model of Alzheimer's disease. Peptides 23:2223-2226.

Banks WA, Robinson SM, Verma S, Morley JE (2003) Efflux of human and mouse amyloid $\beta$ proteins $1-40$ and $1-42$ from brain: impairment in a mouse model of Alzheimer's disease. Neuroscience 121:487-492.

Banks WA, Pagliari P, Nakaoke R, Morley JE (2005) Effects of behaviorally active antibody on the brain uptake and clearance of amyloid beta proteins. Peptides 26:287-294.

Bard F, Cannon C, Barbour R, Burke R, Games D, Grajeda H, Guido T, Hu K, Huang J, Johnson-Wood K, Khan K, Kholodenko D, Lee M, Lieberburg I, Motter R, Nguyen M, Soriano F, Vasquez N, Weiss K, Welch B, et al. (2000) Peripherally administered antibodies against amyloid $\beta$-peptide enter the central nervous system and reduce pathology in a mouse model of Alzheimer's disease. Nat Med 6:916-919.

Best JD, Jay MT, Out F, Ma J, Nadin A, Ellis S, Lewis HD, Pattison C, Reilly M, Harrison T, Shearman MS, Williamson TL, Atack JR (2005) Quantitative measurement of changes in amyloid- $\beta(40)$ in the rat brain and cerebrospinal fluid following treatment with the $\gamma$-secretase inhibitor LY-411575 [ $N^{2}-\left[(2 S)-2-\left(3,5\right.\right.$-difluorophenyl)-2-hydroxyethanoyl]- $N^{1}$ [(7S)-5-methyl-6-oxo-6,7-dihydroxyethanoyl]- $N^{1}$-[(7S)-5-methyl-6-oxo6,7-dihydro-5H-dibenzo[b,d]azepin-7-yl]-L-alaninamide]. J Pharmacol Exp Ther 313:902-908.

Borvak J, Richardson J, Medesan C, Antoke F, Radu C, Simionescu M, Ghetie V, Ward S (1998) Functional expression of the MHC class 1-related receptor, FcRn, in endothelial cells of mice. Int Immunology 10:1289-1298.

Broadwell RD, Sofroniew MV (1993) Serum proteins bypass the bloodbrain fluid barriers to extracellular entry to the central nervous system. Exp Neurol 120:245-263.

Cirrito JR, May PC, O’Dell MA, Taylor JW, Parsadanian M, Cramer JW, Audia JE, Nissen JS, Bales KR, Paul SM, DeMattos RB, Holtzman DM (2003) In vivo assessment of brain interstitial fluid with microdialysis reveals plaque-associated changes in amyloid- $\beta$ metabolism and half-life. J Neurosci 23:8844-8853.

Das P, Murphy MP, Younkin LH, Younkin SG, Golde TE (2001) Reduced effectiveness of A $\beta$ 1-42 immunization in APP transgenic mice with significant amyloid deposition. Neurobiol Aging 22:721-727.

Das P, Howard V, Loosbrock N, Dickson D, Murphy MP, Golde TE (2003) Amyloid- $\beta$ immunization effectively reduces amyloid deposition in FcR $\gamma^{-1-}$ knock-out mice. J Neurosci 23:8532-8538.

Deane R, Yan SD, Submamaryan RK, LaRue B, Jovanovic S, Hogg E, Welch D, Manness L, Lin C, Yu J, Zhu H, Ghiso J, Frangione B, Stern A, Schmidt AM, Armstrong DL, Arnold B, Liliensiek B, Nawroth P, Hofman F, et al. (2003) RAGE mediates amyloid- $\beta$ transport across the blood-brain barrier and accumulation in brain. Nat Med 9:907-913.

Deane R, Wu Z, Sagare A, Davis J, Yan SD, Hamm K, Xu F, Parisi M, LaRue B, Hu HW, Spijkers P, Guo H, Song X, Lenting PJ, Van Nostrand WE, Zlokovic BV (2004) LRP/amyloid $\beta$-peptide interaction mediates differential brain efflux of $A \beta$ isoforms. Neuron 43:333-344. 
DeMattos RB, Bales KR, Cummins DJ, Dodart J, Paul SM, Holtzman DM (2001) Peripheral anti-A $\beta$ antibody alters CNS and plasma $A \beta$ clearance and decreases brain A $\beta$ burden in a mouse model of Alzheimer's disease. Proc Natl Acad Sci USA 98:8850-8855.

DeMattos RB, Bales KR, Cummins DJ, Paul SM, Holtzman DM (2002) Brain to plasma amyloid-A $\beta$ efflux: a measure of brain amyloid burden in a mouse model of Alzheimer's disease. Science 295:2264-2267.

Dodart JC, Bales KR, Gannon KS, Greene SJ, DeMattos RB, Mathis C, DeLong CA, Wu S, Wu X, Holtzman DM, Paul SM (2002) Immunization reverses memory deficits without reducing brain $\mathrm{A} \beta$ burden in Alzheimer's disease model. Nat Neurosci 5:452-457.

Frautschy SA, Cole GM, Baird A (1992) Phagocytosis and deposition of vascular $\beta$-amyloid in rat brains injected with Alzheimer $\beta$-amyloid. Am J Pathol 140:1389-1399.

Gafencu A, Heltianu C, Burlacu A, Hunziker W, Simionescu M (2003) Investigation of IgG receptors expression on the surface of human placental endothelial cells. Placenta 24:664-676.

Hardy J, Selkoe DJ (2002) The amyloid hypothesis of Alzheimer's disease: progress and problems on the road to therapeutics. Science 297:353-356.

Hock C, Konietzko U, Streffer JR, Tracy J, Signorell A, Muller-Tillmanns B, Lemka U, Henke K, Moritz E, Garcia E, Wollmer MA, Umbricht D, deq Uervain JF, Hofmann M, Maddalena A, Papassotiropoulos A, Nitsch RM (2003) Antibodies against $\beta$-amyloid slow cognitive decline in Alzheimer's disease. Neuron 38:547-554.

Hsiao K, Chapman P, Nilsen S, Eckman C, Harigaya Y, Younkin S, Yang F, Cole G (1996) Correlative memory deficits, A $\beta$ elevation, and amyloid plaques in transgenic mice. Science 274:99-102.

Janus C, Pearson J, McLaurin J, Mathews PM, Jiang Y, Schmidt SD, Chishti MA, Horne P, Heslin D, French J, Mount HTJ, Nixon RA, Mercken M, Bergeron C, Fraser PE, St. George- Hyslop P, Westaway D (2000) A $\beta$ peptide immunization reduces behavioral impairment and plaques in a model of Alzheimer's disease. Nature 408:979-982.

Kawarabayashi T, Younkin LH, Saido TC, Shoji M, Ashe KH, Younkin SG (2001) Age-dependent changes in brain, CSF, and plasma amyloid A $\beta$ protein in the Tg2576 transgenic mouse model of Alzheimer's disease. J Neurosci 21:372-381.

Kayed R, Head E, Thompson JL, Mclntire TM, Milton SC, Cotman CW, Glabe CG (2003) Common structure of soluble amyloid oligomers implies common mechanism of pathogenesis. Science 300:486-489.

Kozlowski GP, Nilaver G, Zlokovic BV (1990) Immunoneurology: a serum protein afferent limb to the CNS. Circulating regulatory factors and neuroendocrine function (Porter JC, ed), pp 345-370. New York: Plenum.

LaRue B, Hogg E, Sagare A, Jovanovic S, Maness L, Maurer C, Deane R, Zlokovic BV (2004) Method for measurement of the blood-brain barrier permeability in the perfused mouse brain: application to amyloidbeta peptide in wild type and Alzheimer's Tg 2576 mice. J Neurosci Methods 138:233-242.

Lemere CA, Spooner ET, LaFrancois J, Malester B, Mori C, Leverone JF, Matsuoka Y, Taylor JW, DeMattos RB, Holtzman DM, Clements JD, Selkoe DJ, Duff KE (2003) Evidence for peripheral clearance of cerebral $\mathrm{A} \beta$ protein following chronic, active $\mathrm{A} \beta$ immunization in PSAPP mice. Neurobiol Dis 14:10-18.

LeVine III H (2004) Alzheimer's $\beta$-peptide oligomer formation at physiologic concentrations. Anal Biochem 335:81-90.

Martel CL, Mackic JB, Matsubara E, Governale S, Miguel C, Miao W, McComb JG, Frangione B, Ghiso J, Zlokovic BV (1997) Isoform-specific effects of apolipoproteins E2, E3, and E4 on cerebral capillary sequestration and blood-brain barrier transport of circulating Alzheimer's amyloid beta. J Neurochem 69:1995-2004.

Matsuoka Y, Saito M, LaFrancois J, Saito M, Taylor K, Olm V, Wang L, Casey E, Lu Y, Shiratori C, Lemere C, Duff K (2003) Novel therapeutic approach for the treatment of Alzheimer's disease by peripheral administration of agents with an affinity to A $\beta$-amyloid. J Neurosci 23:29-33.

Morgan D, Diamond DM, Gottschall PE, Ugen KE, Dickey C, Hardy J, Duff K, Jantzen P, DiCario G, Wilcock D, Connor K, Hatcher J, Hope C, Gordon M, Arendash GW (2000) A $\beta$ peptide immunization prevents memory loss in an animal model of Alzheimer's disease. Nature 408:982-985.

Nicoll JAR, Wilkinson D, Holmes C, Steart P, Markham H, Weller RO (2003) Neuropathology of human Alzheimer disease after immunization with amyloid- $\beta$ peptide: a case report. Nat Med 9:448 -452.

Ober RJ, Martinez C, Lai X, Zhou J, Ward SE (2004) Exocytosis of IgG as mediated by the receptor, FcRn: an analysis at the single-molecule level. Proc Natl Acad Sci USA 101:11076-11081.

Oddo S, Billings L, Kesslak JP, Cribbs DH, LaFerla FM (2004) A $\beta$ immunotherapy leads to clearance of early, but not late, hyperphosphorylated tau aggregates via the proteasome. Neuron 43:321-332.

Orgogozo JM, Gilman S, Dartigues JF, Laurent B, Puel M, Kirby LC, Jouanny P, Dubios B, Eisner L, Flitman S, Michel BF, Boada M, Frank A, Hock C (2003) Subacute meningeoencephalitis in a subset of patients with AD after $A \beta 42$ immunization. Neurology 61:46-54.

Pan W, Solomon B, Maness LM, Kastin AJ (2002) Antibodies to $\beta$-amyloid decrease the blood-to-brain transfer of $\beta$-amyloid peptide. Exp Biol Med 227:609-615.

Pardridge WM (1991) Antibody delivery through the blood-brain barrier. In Peptide drug delivery to the brain (Pardridge WM, ed), pp 219-238. New York: Raven.

Paresce DM, Chung H, Maxfield FR (1997) Slow degradation of aggregates of the Alzheimer's disease amyloid $\beta$-protein by microglia cells. J Biol Chem 272:29390-29397.

Ravetch JV, Bolland S (2001) IgG Fc receptors. Annu Rev Immunol 19:275-290.

Roopenian DC, Christianson GJ, Sproule TJ, Brown AC, Akilesh S, Jung N, Petkova S, Avanessian L, Choi EY, Shaffer DJ, Eden PA, Anderson CL (2003) The MHC1-like IgG receptor controls perinatal IgG transport, IgG homeostasis and fate of IgG-Fc-coupled drugs. J Immunol 170:3528-3533.

Schenk D, Barbour R, Dunn W, Gordon G, Grajeda H, Guido T, Hu K, Huang J, Johnson-Wood K, Khan K, Kholodenko D, Lee M, Liao Z, Lieberburg I, Motter R, Mutter L, Soriano M, Shopp G, Vasquez G, Vandevert C, et al. (1999) Immunization with amyloid- $\beta$ attenuates Alzheimer-disease-like pathology in the PDAPP mouse. Nature 400:173-177.

Schlachetzki F, Zhu C, Pardridge WM (2002) Expression of the neonatal Fc receptor (FcRn) at the blood-brain barrier. J Neurochem 81:203-206.

Shibata M, Yamada S, Kumar SR, Calero M, Bading J, Frangione B, Holtzman DM, Miller CA, Strickland DK, Ghiso J, Zlokovic BV (2000) Clearance of Alzheimer's amyloid-A $\beta_{1-40}$ peptide from brain by low-density lipoprotein receptor-related protein-1 at the blood-brain barrier. J Clin Invest 106:1489-1499.

Sigurdsson EM, Scholtzova H, Mehta PD, Frangione B, Wisniewski T (2001) Immunization with a nontoxic/nonfibrillar amyloid- $\beta$ homologous peptide reduces Alzheimer's disease-associated pathology in transgenic mice. Am J Pathol 159:439-447.

Tanzi RE, Moir RD, Wagner SL (2004) Clearance of Alzheimer's A $\beta$ peptide; the many roads to perdition. Neuron 43:605-608.

Thorell JI, Johansson BG (1971) Enzymatic iodination of polypeptides with ${ }^{125}$ I to high specific activity. Biochim Biophys Acta 251:363-366.

Wilcock DM, DiCarlo G, Henderson D, Jackson J, Clarke K, Ugen KE, Gordon MN, Morgan D (2003) Intracranially administered anti-A $\beta$ antibody reduce $\beta$-amyloid deposition by mechanisms both independent of and associated with microglial activation. J Neurosci 23:3745-3759.

Wu Z, Hofman FM, Zlokovic BV (2003) A simple method for isolation and characterization of mouse brain microvascular endothelial cells. J Neurosci Methods 130:53-63.

Yang F, Lim GP, Begum AN, Ubeda OJ, Simmons MR, Ambegaokar SS, Chen P, Kayed R, Glabe CG, Frautschy SA, Cole GM (2005) Curcumin inhibits formation of amyloid $\beta$ oligomers and fibrils, binds plaques, and reduces amyloid in vivo. J Biol Chem 280:5892-5901.

Yoshida M, Claypool SM, Wagner JS, Mizoguchi E, Mizoguchi A, Roopenian DC, Lencer WI, Blumberg RS (2004) Human neonatal Fc receptor mediates transport of IgG into luminal secretions for delivery of antigens to mucosal dendritic cells. Immunity 20:769-783.

Zlokovic BV (2004) Clearing amyloid through the blood-brain barrier. J Neurochem 89:807-811.

Zlokovic BV (2005) Neurovascular mechanisms of Alzheimer's neurodegeneration. Trends Neurosci 28:202-208.

Zlokovic BV, Skundric DS, Segal MB, Lipovac MN, Mackic JB, Davson H (1990) A saturable mechanism for transport of immunoglobulin G across the blood-brain barrier of the guinea pig. Exp Neurol 107:263-270.

Zlokovic BV, Mackic JB, Wang L, McComb JG, McDonough A (1993) Differential expression of $\mathrm{Na}, \mathrm{K}-\mathrm{ATP}$ ase alpha and beta subunit isoforms at the blood-brain barrier and the choroid plexus. J Biol Chem 268:8019-8025. 